\title{
Design and construction of a deep excavation in soft soils adjacent to the Shanghai Metro tunnels
}

\author{
Z.F. Hu, Z.Q. Yue, J. Zhou, and L.G. Tham
}

\begin{abstract}
This paper presents the design and construction of a deep excavation for building foundations in saturated soil. This deep excavation was of particular interest because it was located above and beside the Shanghai Metro tunnels. The twin Shanghai Metro tunnels had to be in full operation during the deep excavation. Potential large deformation of the twin tunnels was one of the main concerns during the design and construction for the deep excavation. The paper discusses in detail the criteria and measures for controlling the soil and tunnel deformation. The measures included cast-in-place concrete diaphragm walls with bracing structural members, pumping consolidation, cement-soil mix pile systems, and rational excavation procedures. A simplified theoretical method was proposed to estimate the increment in undrained shear strength in a soft clay layer due to pumping consolidation. Furthermore, conventional finite element methods were used to predict the soil vertical and horizontal displacements induced by the excavation. Using the design and construction methods discussed in the paper, the settlement and horizontal displacement of the tunnels were successfully controlled within $5.0 \mathrm{~mm}$ and $9.0 \mathrm{~mm}$, respectively. The curvature of longitudinal deformation curve of the tunnels was less than $1 / 15000$. The horizontal displacement of the braced diaphragm walls was less than $0.12 \%$ of the total excavation depth.
\end{abstract}

Key words: Metro tunnels, saturated soft soil, deep excavation, design, construction, ground improvement, case studies.

\begin{abstract}
Résumé : Cet article présente la conception et la construction d'une excavation profonde pour la construction de fondations dans des sols saturés mous. Cette fondation profonde était particulière en ce qu'elle était située au-dessus et à côté des tunnels du métro de Shanghai. Les tunnels du métro sont jumelés et devaient rester en opération continuelle durant les travaux pour l'excavation profonde. Une déformation potentiellement importante des tunnels jumelés constituait une des principales préoccupations lors de la conception et de la construction de l'excavation profonde. Cet article discute en détail les critères et des mesures prises pour contrôler le sol et la déformation des tunnels. Les mesures comportaient des parois moulées en béton avec des membrures de contreventement, de la consolidation par pompage, des systèmes de pieux mixes de sol-ciment et des procédures rationnelles d'excavation. On a proposé une méthode théorique simplifiée pour estimer l'accroissement de la résistance au cisaillement dans la couche d'argile molle dû à la consolidation par pompage. De plus, on a utilisé des méthodes d'éléments finis conventionnelles pour prédire les déplacements horizontaux et verticaux du sol induits par l'excavation. En utilisant les méthodes de conception et de construction discutées dans cet article, le tassement et le déplacement horizontal des tunnels ont été contrôlés avec succès à moins de 5,0 mm et 9,0 $\mathrm{mm}$ respectivement. La courbure de la courbe de déformation longitudinale des tunnels était inférieure à $1 / 15000$. La déformation horizontale de la paroi moulée étayée était inférieure à $0.12 \%$ de la profondeur totale de l'excavation.
\end{abstract}

Mots clés : tunnels de métro, sol mou saturé, excavation profonde, conception, construction, amélioration du terrain, études de cas.

[Traduit par la Rédaction]

\section{Introduction}

Shanghai is one of the largest and most well-known cities in China and around the world. Shanghai has a population exceeding 13 million and a municipal area of about

Received 5 February 2002. Accepted 1 May 2003. Published on the NRC Research Press Web site at http://cgj.nrc.ca on 17 September 2003.

Z.F. Hu and J. Zhou. Department of Geotechnical Engineering, Tongji University, Shanghai, 200092, People's Republic of China.

Z.Q. Yue ${ }^{1}$ and L.G. Tham. Department of Civil

Engineering, The University of Hong Kong, Pokfulam Road, Hong Kong, People's Republic of China.

${ }^{1}$ Corresponding author (e-mail: yueqzq@hkucc.hku.hk).
$6340 \mathrm{~km}^{2}$. With the rapid economic development and reform of the last two decades, Shanghai has been gradually regaining its reputation as an international economic, financial, commercial, and industrial center. Accordingly, construction activities of civil infrastructures and buildings in the Municipality of Shanghai have been increasing significantly. The intention of this paper is to introduce one of these activities, namely the design and construction of a deep excavation for a commercial building located closely above and beside the Shanghai Metro tunnel 1.

\section{Background}

\subsection{Shanghai Metro tunnels}

Shanghai Metro line 1, as one of the main components of the municipal transportation network, is located in the down- 
town area of Shanghai, an area with a dense network of buildings, roads, streets, and urban infrastructure, as shown in Fig. 1. Metro line 1 runs north and south and carries a very large number of passengers every day.

Metro line 1 was constructed between 1990 and 1994 and commenced operation in April 1995. An extension of the line in the south end was completed in 1997. At present, Shanghai Metro line 2 is being constructed and runs from east to west (see Fig. 1).

Metro line 1 has 16 stations and a total length of $21.615 \mathrm{~km}$, which comprises an $18.620 \mathrm{~km}$ long underground tunnel and a $2.995 \mathrm{~km}$ long aboveground section of track.

The underground tunnels have two different cross sections, namely circular and rectangular. The tunnels with a circular cross section were fabricated with six pieces of reinforced concrete lining segments and have an internal diameter of $5.5 \mathrm{~m}$ and an external diameter of $6.2 \mathrm{~m}$. The tunnels with a rectangular cross section were constructed using castin-place reinforced concrete and are $4.3 \mathrm{~m}$ in width and $5.0 \mathrm{~m}$ in height for a single line and 9.5-14.6 $\mathrm{m}$ in width and $5.0 \mathrm{~m}$ in height for a double line.

The deep excavation discussed in this paper is located closely adjacent to the tunnels between People's Park Station and Xin Zha Road Station, as shown in Figs. 1 and 2. The excavation was carried out adjacent to the tunnels and their auxiliary facilities when they were in full function. Consequently, many difficulties and problems were anticipated for the design and construction of the deep excavation.

\subsection{Ground conditions}

The Municipality of Shanghai is located in the front fringe of the Yangtze River Delta (Fig. 1). The ground soils are mainly thick soft soils comprising Quaternary alluvial and marine deposits. In view of the soil properties, the engineering geological investigation is very important and must meet the following basic requirements:

(1) The investigation must satisfy the requirements of geotechnical design for each stage; geological profiles must be plotted based on logs from sufficient boreholes to ensure the reliability and continuity of the data.

(2) The investigation must provide enough in situ measured data and soil parameters for calculation and analysis of stability and deformation of the subgrade. Apart from the general geological data, according to the requirements of the deep excavation adjacent to Metro line 1, some special soil tests should be carried out. The test data may include recompression values, modulus of resilience, rebound and recompression curves, horizontal resistance coefficient, and undrained shear strength.

(3) In addition to the routine hydrogeological data, some specific hydrogeological investigations were also carried out. These investigations include the variations of discharge and water tables adjacent to Metro line 1, the permeability of each soil layer, the soil connectivity to nearby water courses, the distribution of water-table aquifers and water-resisting layers, water head pressure, and flow velocity of artesian aquifers.

The engineering geological investigations for Metro line 1 commenced in 1958. A total of 936 boreholes were systematically explored in urban and suburban areas. These bore- holes include 155 drilled to a depth of $50 \mathrm{~m}, 48$ drilled to a depth of $100 \mathrm{~m}$, and 170 drilled into bedrock. The borehole data were kept in geological archives.

As part of the engineering feasibility study, geological data from 43 boreholes related to Metro line 1 and other construction activities were collected and studied. In the schematic design stage, a further 64 boreholes were drilled and 1760 tubes of soil samples were collected. In the stage of preparing construction design drawing, some boreholes were drilled along the twin Metro tunnels about $10 \mathrm{~m}$ to the axis line and an additional two $25 \mathrm{~m}$ deep boreholes were drilled for pumping tests near the banks of the $\mathrm{Su}$ Zhou River.

Based on the findings of the geological investigations, the ground soils up to $50 \mathrm{~m}$ in depth along Metro line 1 can be divided into seven different soil layers. The soil layer profiles perpendicular and parallel to the tunnels are shown in Figs. 3 and 4, respectively. The locations of the two cross sections I-I and II-II are shown in Fig. 2. A detailed description of the $50 \mathrm{~m}$ thick ground soil layers is given in Table 1 . The engineering properties of the soils at the deep excavation site are given in Tables 2 and 3. In general, the soils surrounding the Metro tunnels and stations are mainly gray very soft silty clay and gray very soft clay and have the following characteristics: large void ratio, high plasticity, poor permeability, high water content, low shear strength, and low modulus of deformation.

\subsection{Deep excavation}

Deep excavation was required for the construction of the Shanghai New World Commercial City Complex. The site completely spans the north- and south-bound tunnels of Metro line 1, as shown in Figs. 2 and 5. The building foundations have east, west, and middle sections. The deep excavations for the east and west foundations were only $3.0 \mathrm{~m}$ from the sides of the Metro tunnels and that for the middle foundation was about $3.0 \mathrm{~m}$ above the top of the Metro tunnels. In addition, many underground utilities including gas, telephone, electricity, fresh-water main, storm-water main, and sewage pipes were distributed around the deep excavations. One of the utilities was located only $1.0 \mathrm{~m}$ from the building restriction line.

The east, west, and middle excavation sites have areas of 1689, 2240, and $1800 \mathrm{~m}^{2}$ and excavation depths of 11.5 , 12.5 , and 4.4-5.2 $\mathrm{m}$, respectively. The excavations were to be carried out in saturated soft soils with very high plasticity, as discussed previously.

\section{Criteria for deformation control}

It was clear that the deep excavations were very difficult and resulted in many areas of concern. In particular, the deep excavations were in saturated soft soils surrounding the operating Metro tunnels, conditions not previously encountered in Mainland China. A detailed investigation of various issues was carried out, and the following design criteria for controlling deformation of the Metro tunnels were determined: $(i)$ both horizontal and vertical maximum deformation including the final settlement after the building loading in the Metro tunnels of $\leq 20 \mathrm{~mm}$; (ii) maximum rebound in the Metro tunnel of $15 \mathrm{~mm}$; (iii) curvatures of the longitudi- 
Fig. 1. Location plan of Shanghai and Metro lines 1 and 2.

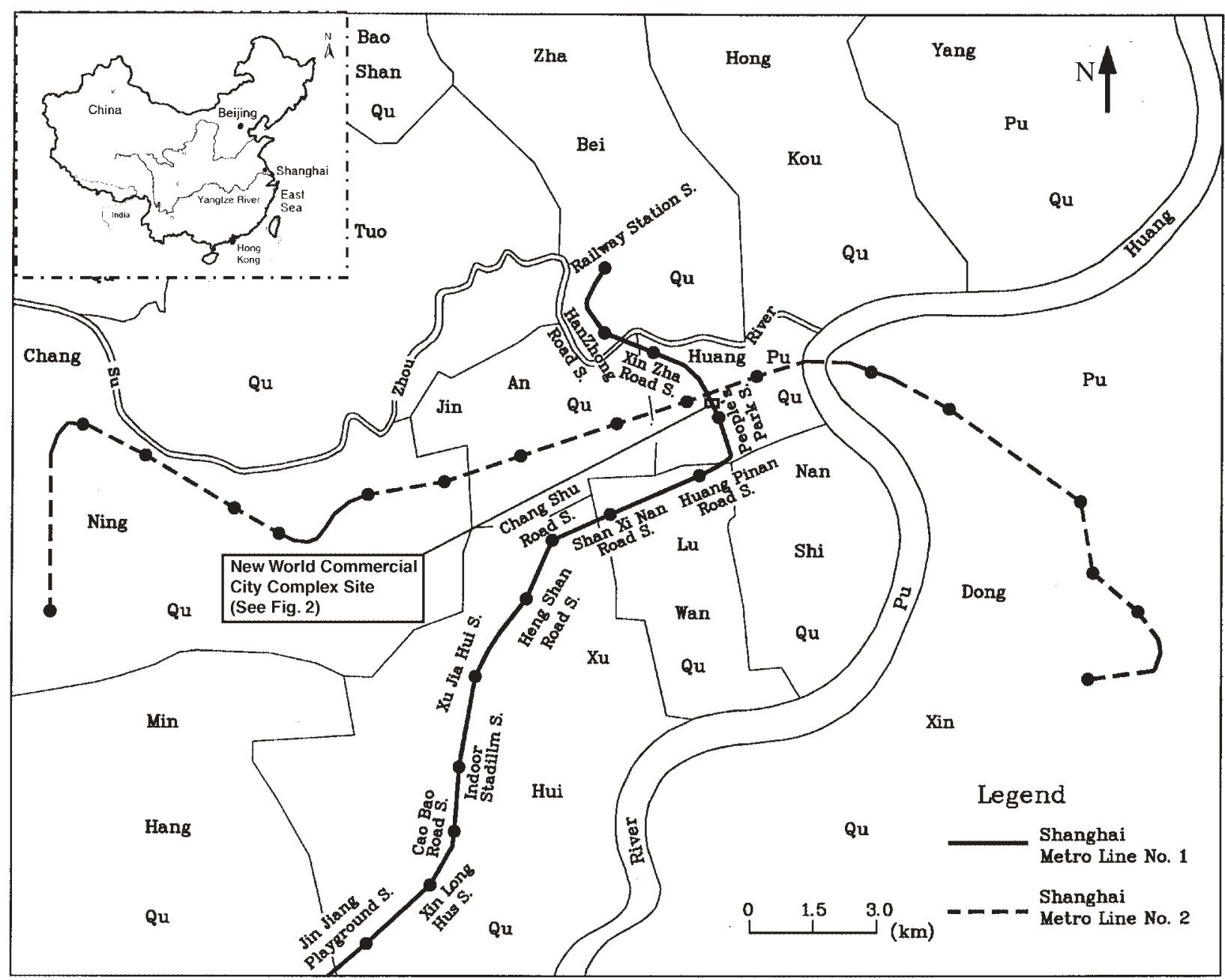

nal deformation curve in the Metro tunnel of $\leq 1 / 15000$; (iv) lateral deformations of the cross-section diameters arising from longitudinal displacements of the Metro tunnel lining structure of $\leq 10 \mathrm{~mm}$; $(v)$ additional loads on the tunnel external walls caused by the vertical loads of the building and some construction activities such as pumping and injecting of $\leq 20 \mathrm{kPa}$; and ( $v i$ ) peak velocity of the vibration of the tunnels induced by piling and blasting the bracing members of $\leq 2.5 \mathrm{~cm} / \mathrm{s}$.

\section{Design and construction measures}

\subsection{General}

The design scheme and construction measures for effectively bracing walls and controlling soft soil deformation for the deep excavation were proposed after the completion of relevant calculations and analyses, leading to the following acceptable results: $(i)$ the actual measured values of maximum settlement and horizontal displacement were only 5.0 and $9.0 \mathrm{~mm}$, respectively; (ii) the curvatures of the longitudinal deformation curve in the tunnels were $\leq 1 / 15000$; and (iii) the maximum horizontal displacement of the bracing walls was only $0.12 \%$ of the excavation depth $H$, where $H$ was 11.5 and $12.5 \mathrm{~m}$ for the east and west excavation sites, respectively. A detailed description of the design scheme and construction measures is given in the following sections.

\subsection{Bracing structural system}

The bracing structural system, consisting of diaphragm walls and bracing structural members, was used to provide lateral support for the deep excavation of the east and west foundation sites. The diaphragm walls were made of cast-inplace reinforced concrete $800 \mathrm{~mm}$ thick and had an embedded depth of $0.83 \mathrm{H}$ into the subsoil below the bottom of the excavation (Fig. 5).

The bracing structural members were installed at three levels (Fig. 5). The cross sections of the primary bracing members had an area of $1000 \times 1000 \mathrm{~mm}^{2}$ and were located with $9.0 \mathrm{~m}$ vertical and horizontal spacing into the diaphragm walls. Square hollow steel vertical props were poured in the member joints. The vertical props were made up of four pieces of $\mathrm{L}_{160 \times 160 \times 16}$ hot-rolling equilateral angle steel welded with tie plates. The prop lower ends were inserted $4.0 \mathrm{~m}$ into bored cast-in-place piles.

The primary bracing members were rigidly connected to the diaphragm wall passing reinforced concrete enclosure purlines with $800 \times 1000 \mathrm{~mm}^{2}$ sections. Bracing was established in both ends of the primary bracing members. The primary bracing members along the east to west direction in 
Fig. 2. Plan of the design and construction for the deep excavation at Shanghai New World Commercial City Complex. All dimensions in metres.

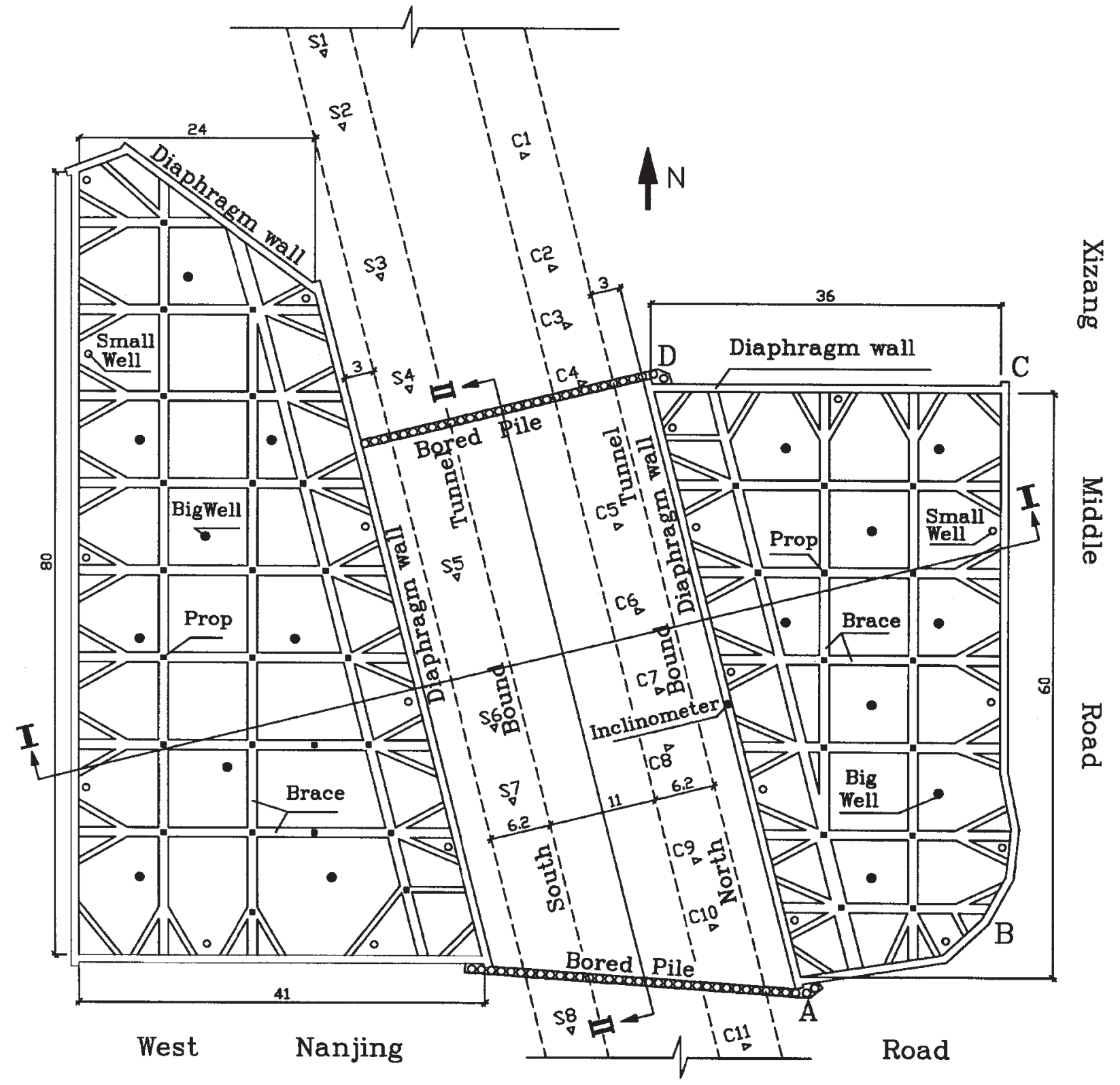

Fig. 3. Geological cross section I-I perpendicular to the Metro tunnels. All dimensions in metres.

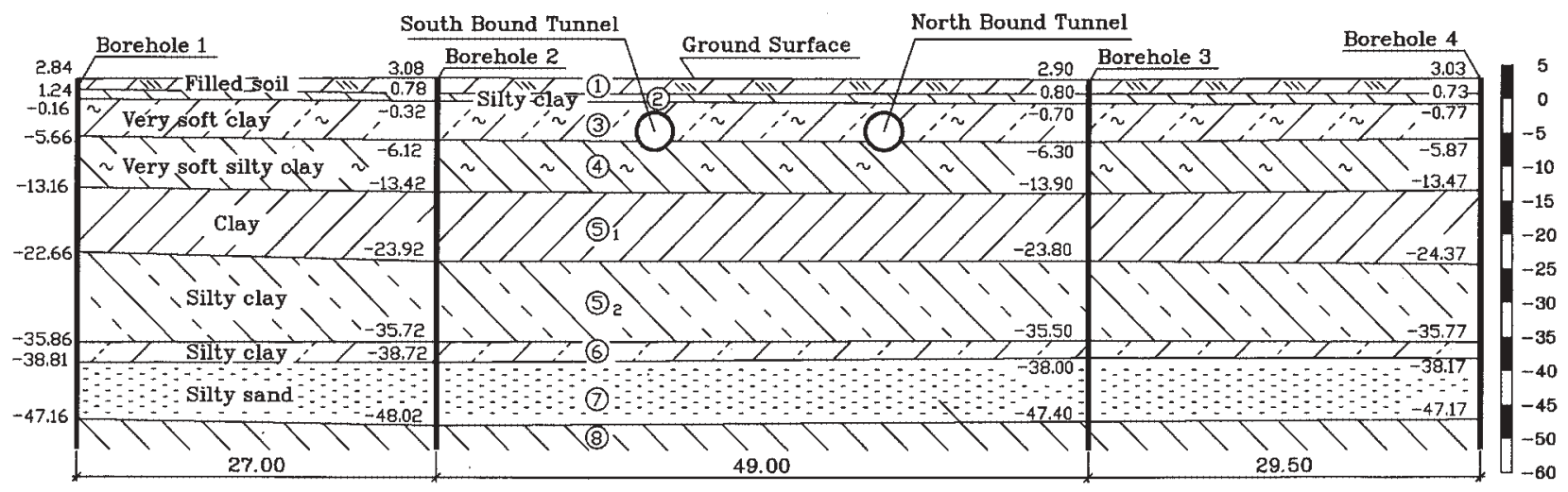


Fig. 4. Geological cross section II-II parallel to the Metro tunnels. All depths in metres.

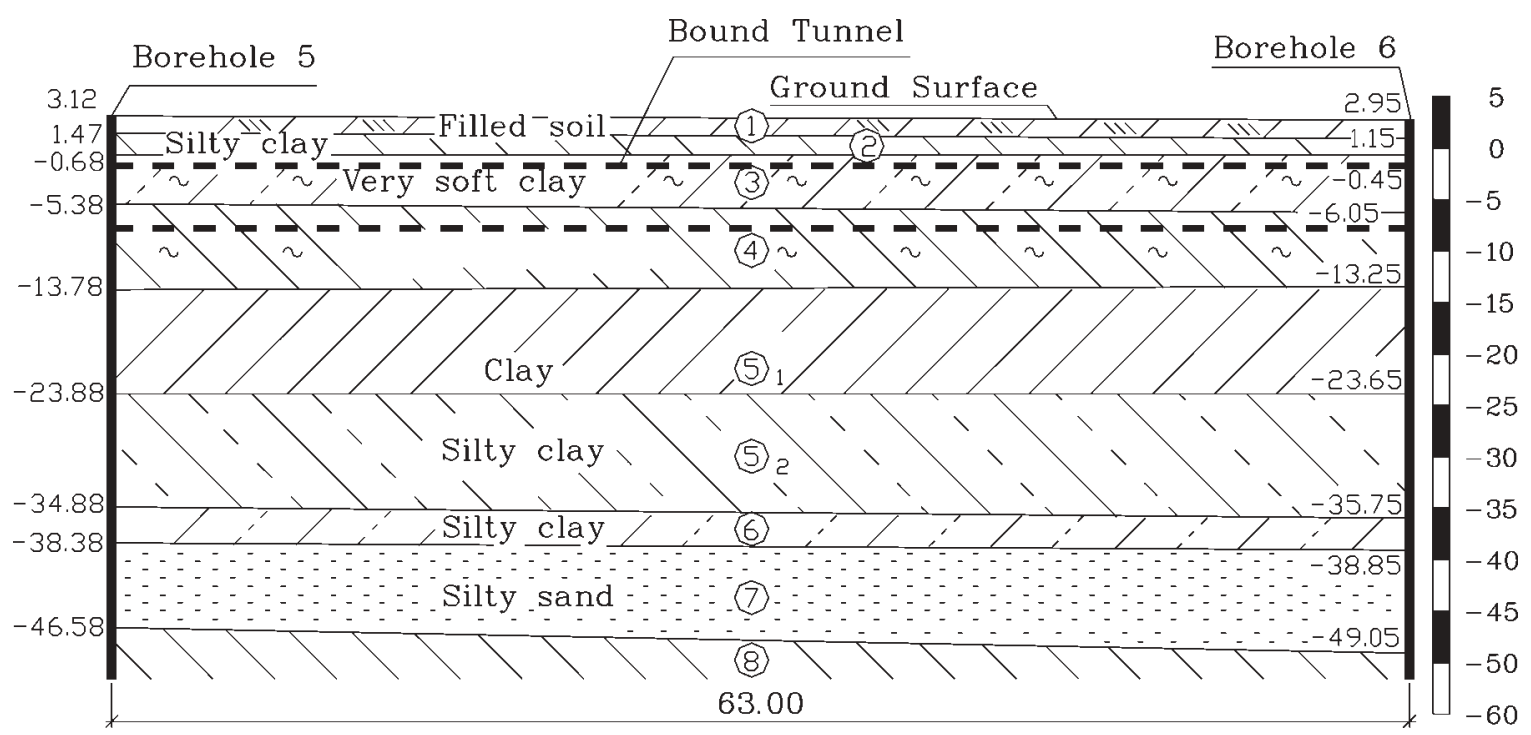

Table 1. Profile and geological description of the soils located along Shanghai Metro line 1.

\begin{tabular}{|c|c|c|c|c|}
\hline Period & $\begin{array}{l}\text { Soil } \\
\text { classification }\end{array}$ & $\begin{array}{l}\text { Layer } \\
\text { No. }\end{array}$ & $\begin{array}{l}\text { Thickness } \\
(\mathrm{m})\end{array}$ & Engineering geological description \\
\hline \multirow[t]{3}{*}{ Later Holocene Epoch $\left(\mathrm{Q}_{4}{ }^{3}\right)$} & Artificial fill & $1-1$ & $0.5-2.0$ & $\begin{array}{l}\text { Mainly brownish yellow, gray clay; contains large quantities } \\
\text { of building rubble; loose; wholly distributed along the } \\
\text { Metro line }\end{array}$ \\
\hline & Creek fill & $1-2$ & $1.0-3.0$ & $\begin{array}{l}\text { Black sludge; contains organic matter, bad smell; saturated; } \\
\text { very high plasticity; distributed sporadically }\end{array}$ \\
\hline & Sandy silt & $2-2$ & $2.0-10.0$ & $\begin{array}{l}\text { Gray; nonuniform; clayey; medium compressibility; saturated; } \\
\text { slightly dense; distributed at the north of Xin Zha Road }\end{array}$ \\
\hline Middle Holocene Epoch $\left(\mathrm{Q}_{4}{ }^{2}\right)$ & $\begin{array}{l}\text { Very soft silty } \\
\text { clay }\end{array}$ & 3 & $1.5-8.0$ & $\begin{array}{l}\text { Gray; contains mica, organic matter, and silty sand; high com- } \\
\text { pressibility; saturated; high plasticity; wholly distributed } \\
\text { along the Metro line }\end{array}$ \\
\hline \multirow[t]{2}{*}{ Early Holocene Epoch $\left(\mathrm{Q}_{4}{ }^{1}\right)$} & Clay & $5-1$ & $7.0-20.0$ & $\begin{array}{l}\text { Gray; contains calcium nodules and organic matter; medium to } \\
\text { slightly high compressibility; very wet; high plasticity; dis- } \\
\text { tributed extensively }\end{array}$ \\
\hline & Silty clay & $5-2$ & $3.0-20.0$ & $\begin{array}{l}\text { Gray; contains organic matter; medium compressibility; dis- } \\
\text { tributed locally }\end{array}$ \\
\hline \multirow[t]{2}{*}{ Middle Pleistocene Epoch $\left(\mathrm{Q}_{3}{ }^{2}\right)$} & Silty clay & 6 & $2.0-4.5$ & $\begin{array}{l}\text { Blackish green; with inclusions of iron oxide spots and } \\
\text { calcium nodules; low compressibility; very wet; medium to } \\
\text { low plasticity; distributed widely }\end{array}$ \\
\hline & Silty sand & $7-1$ & $5.0-10.0$ & $\begin{array}{l}\text { Greenish yellow; containing mica and clay; saturated; medium } \\
\text { dense; distributed along the Metro line }\end{array}$ \\
\hline
\end{tabular}

the east and west excavation sites were arranged in the same axis lines. Thus, the members constitute a stable bracing system as shown in Fig. 2.

In addition, a reinforced concrete lock beam was poured along the top of the whole diaphragm walls. As a result, the overall stiffness of the bracing structural system for the east and west excavations was enhanced. Consequently, both the horizontal displacement of the wall prior to the establishing of the first strut and the additional deformation caused by asymmetric and unbalanced unloading during the excavations can be decreased noticeably.

\subsection{Deformation analysis}

Computational analyses of the soil-structural system with 
Table 2. Geotechnical properties and parameters of the foundation soils at the Shanghai New World Commercial City Complex.

\begin{tabular}{|c|c|c|c|c|c|c|c|}
\hline $\begin{array}{l}\text { Layer } \\
\text { No. }\end{array}$ & Soil classification & Thickness (m) & $\begin{array}{l}\text { Layer bottom } \\
\text { depth }(\mathrm{m})\end{array}$ & $\begin{array}{l}\text { Liquid limit, } \\
\text { LL }(\%)\end{array}$ & $\begin{array}{l}\text { Plastic } \\
\text { limit, PL } \\
(\%)\end{array}$ & $\begin{array}{l}\text { Coefficient } \\
\text { of earth } \\
\text { pressure at } \\
\text { rest, } K_{0}\end{array}$ & $\begin{array}{l}\text { Water } \\
\text { content, } \\
w(\%)\end{array}$ \\
\hline 2 & Silty clay & $1.10-2.15$ & $3.0-3.8$ & 38.4 & 22.2 & - & 34.0 \\
\hline 3 & Very soft silty clay & $4.70-5.80$ & $8.5-9.2$ & 39.0 & 25.1 & 0.49 & 43.4 \\
\hline 4 & Very soft clay & $7.20-8.40$ & $16.0-16.9$ & 46.8 & 27.0 & 0.52 & 48.6 \\
\hline 6 & Silty clay & $2.40-3.50$ & $40.9-41.8$ & 30.9 & 19.1 & - & 22.6 \\
\hline $7-1$ & Silty sand & $8.35-10.20$ & $49.7-52.0$ & - & - & - & 27.6 \\
\hline
\end{tabular}

Note: $c$ and $\phi$ were obtained from the consolidated quick direct shear test.

Table 3. Results of in situ vane shear tests for the undrained shear strength, $S_{\mathrm{u}}$, of soft soil layer 4 before and after pumping.

\begin{tabular}{|c|c|c|c|c|}
\hline Soil classification & Value & $\begin{array}{l}\text { Field vane shear } \\
\text { strength, } S_{\mathrm{u}} \text {, before } \\
\text { pumping }(B)(\mathrm{kPa})\end{array}$ & $\begin{array}{l}\text { Field vane shear } \\
\text { strength, } S_{\mathrm{u}} \text {, after } \\
\text { pumping }(A)(\mathrm{kPa})\end{array}$ & $\begin{array}{l}\text { Vane shear strength } \\
\text { increase }=[(A-B) / B] \times \\
100(\%)\end{array}$ \\
\hline \multirow[t]{3}{*}{ Gray very soft clay } & Minimum & 19 & 27 & 42 \\
\hline & Maximum & 29 & 35 & 21 \\
\hline & Mean & 22 & 30 & 36 \\
\hline
\end{tabular}

Fig. 5. Cross section of the design and construction for the deep excavation at Shanghai New World Commercial City Complex. All dimensions in metres.

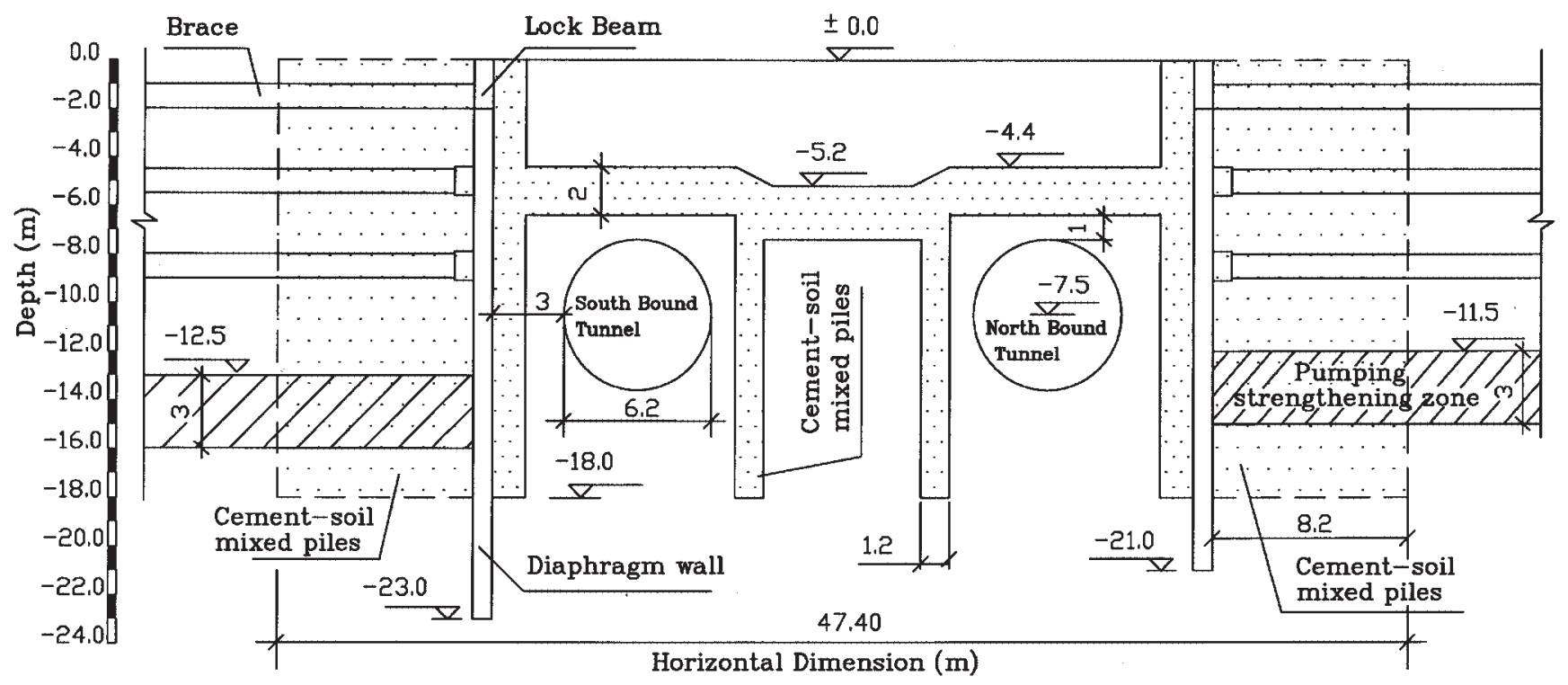

the support of the bracing structural system described previously showed that the horizontal maximum displacement of the diaphragm walls would be about $28.5 \mathrm{~mm}$, and the maximum settlement of the ground adjoining the walls would be about $23.1 \mathrm{~mm}$. Such limited displacements and settlement would not severely affect the foundation excavation and building structure construction safety and the environment around the building. These displacements would affect some special areas closely adjacent to the operating Metro tunnels, however. This issue had to be resolved for the safe operation of the Metro tunnels.
The bracing structural system has adequate strength, stiffness, and stability. Its vertical stiffness coefficient $E I / h^{4}$ was estimated at about 6.17 or $11.44 \mathrm{MPa}$, where $E$ $(=21700 \mathrm{MPa})$ and $I\left(=1.0 \times 0.8^{3} / 12=0.0427 \mathrm{~m}^{4}\right)$ are the elastic modulus and the moment of inertia of the cross section of the diaphragm walls, respectively; and $h(=3.5$ or $3.0 \mathrm{~m}$ ) is the vertical spacing of the bracing members. In Shanghai, a bracing structural system for excavation pits can be considered structurally stable if its vertical stiffness coefficient $E I / h^{4}$ is greater than $2.0 \mathrm{MPa}$. Thus the bracing structural system was considered structurally stable. 


\begin{tabular}{|c|c|c|c|c|c|c|c|}
\hline $\begin{array}{l}\text { Unit weight, } \\
\gamma\left(\mathrm{kN} / \mathrm{m}^{3}\right)\end{array}$ & $\begin{array}{l}\text { Void } \\
\text { ratio, } e\end{array}$ & $\begin{array}{l}\text { Modulus of } \\
\text { deformation, } \\
E_{\mathrm{s}}(\mathrm{MPa})\end{array}$ & $\begin{array}{l}\text { Field vane shear } \\
\text { strength, } S_{\mathrm{u}} \\
(\mathrm{kPa})\end{array}$ & $\begin{array}{l}\text { Cohesion, } \\
c(\mathrm{kPa})\end{array}$ & $\begin{array}{l}\text { Angle of } \\
\text { internal } \\
\text { friction, } \phi\left(^{\circ}\right)\end{array}$ & $\begin{array}{l}\text { Horizontal } \\
\text { permeability } \\
\text { coefficient, } K_{\mathrm{h}} \\
(\mathrm{cm} / \mathrm{s})\end{array}$ & $\begin{array}{l}\text { Vertical } \\
\text { permeability } \\
\text { coefficient, } K_{\mathrm{v}} \\
(\mathrm{cm} / \mathrm{s})\end{array}$ \\
\hline 17.6 & 1.22 & 2.93 & 25 & 7.0 & 14.0 & $1.27 \times 10^{-5}$ & $1.41 \times 20^{-6}$ \\
\hline 17.2 & 1.37 & 2.45 & 22 & 7.5 & 9.5 & $1.19 \times 10^{-6}$ & $1.13 \times 10^{-7}$ \\
\hline 22.0 & 0.67 & 8.60 & - & 36.5 & 15.5 & - & - \\
\hline 18.9 & 0.81 & 14.47 & - & 5.0 & 23.0 & - & - \\
\hline
\end{tabular}

The data given in the previous paragraph indicated that the displacements could be mainly due to the deformation of the saturated soft soils beneath the bottom of the excavation sites. It was therefore necessary to improve the properties and strength of the soft soils to reduce any possible large displacement of the special areas closely adjacent to the operating Metro tunnels.

The soil stress states in the internal and external sides of the braced walls changed significantly during the excavation. Horizontal stresses in the excavation area could increase rapidly, so shear stress at some points in the soil may reach the soil shear strength. Thus local plastic zones that could lead to heave of the soil body could develop subsequently near the bottom of the excavation. At the same time, the soil body behind the walls could move toward the excavation area and lead to a decrease in the horizontal stress and an increase in the shear stress. Consequently, some points of the excavation could attain the state of limit equilibrium so that plastic flow could emerge locally.

With further excavation, the elevation difference between the internal and external sides of the braced walls would increase. Thus the magnitude and scope of the shear stress induced by the additional soil body load would be enlarged, which could result in more and more plastic regions in the soils. Large horizontal displacement and vertical settlement could be generated accordingly. Therefore, large plastic deformation around the excavation and rheologic slip of the deep soils would be present in the soils supported by the stable bracing structural system because some soils beneath the bottom of the excavation sites could enter into a limit equilibrium state.

Moreover, saturated soft soils in Shanghai possess some special rheologic property as illustrated in Fig. 6 (Liu 1999). Details of the testing can be found in Liu (1999). With the passage of experiment time, the strain of the undrained soil specimen increases very rapidly to failure while the strain of the drained soil specimen increases slightly when $\sigma_{1} \leq$ $150 \mathrm{kPa}$, where the cell pressure $\sigma_{3}=K_{0} \sigma_{1}$ and $K_{0}$ is the soil static earth pressure coefficient. The stress level at $150 \mathrm{kPa}$ corresponds to the stress level in the passive zone for an excavation depth up to 14 or $15 \mathrm{~m}$. Therefore, the plastic region and slippage of soils behind the walls could be reduced effectively provided that the soft soils in the bottom of the excavation were adequately stabilized and strengthened. Ac-
Fig. 6. Rheologic test results for the soft soils in Shanghai.

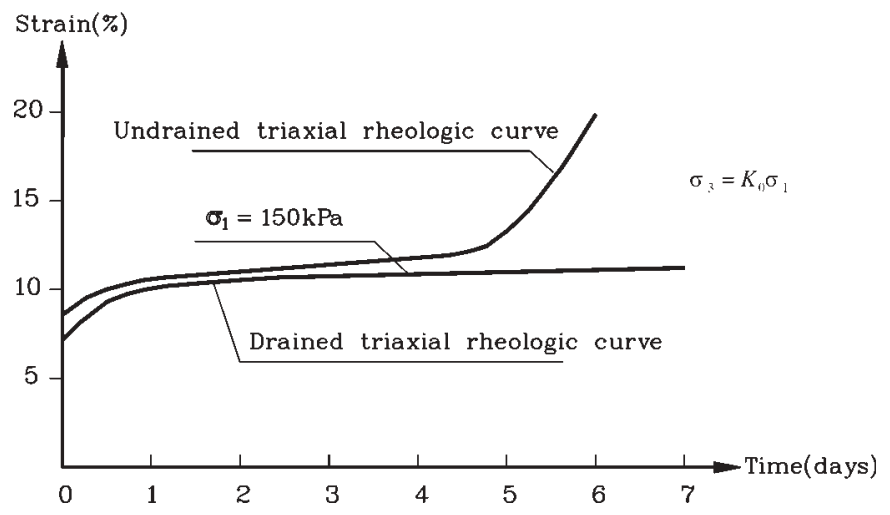

cordingly, the following deformation control measures were adopted.

\subsection{Pumping consolidation}

Pumping consolidation or precompression by pumping water out of ground was used to reduce the amount of water in soft soil layers and to improve the soil shear strength and deformation modulus before excavation. The potential for heave and lateral movement in the originally soft soil layers located beneath and surrounding the excavation, respectively, could then be significantly reduced. Based on an estimation of the pumping consolidation, a pumping and dewatering system was design and constructed as follows.

A single, large dewatering well was designed and constructed for about every $200 \mathrm{~m}^{2}$ of plan area of the excavation sites. Each large dewatering well was 19.0 and $21.0 \mathrm{~m}$ in depth for the east and west excavation sites, respectively. The wells were inserted into clay layers 4 and 5 and consisted of a borehole $650 \mathrm{~mm}$ in diameter and a dewatering pipe $250 \mathrm{~mm}$ in diameter. Plan arrangement of the large dewatering wells was in the form of an equilateral triangle, as shown in Fig. 2.

One small dewatering well was constructed for about every $20 \mathrm{~m}^{2}$ of plan area of the excavation site. Each small dewatering well was 17.0 and $19.0 \mathrm{~m}$ in depth for the east and west excavation sites, respectively. The wells were inserted into clay layers 4 and 5 and consisted of a borehole $450 \mathrm{~mm}$ in diameter and a well pipe $150 \mathrm{~mm}$ in diameter. 
Plan arrangement of the small wells was along the internal of the diaphragm walls, as shown in Fig. 2.

A deep-well pump with a long axis was placed in each dewatering well. Every three dewatering wells were connected to a vacuum pump through sealed pipes. The design vacuum pressure was greater than $50 \mathrm{~Pa}$. The pumping time schedule was from the 28th day before the excavation to the 7th day after the completion of the foundation slab concrete. Pumping in the large wells was scheduled longer until the 7th day after the completion of the foundation cushion. Deep-well vacuum pumping devices were then used to carry out pumping of the groundwater in the saturated soil layers. The ultimate design depth of the pumping water table was about 3.0-4.0 m beneath the bottom of the excavation.

Free water in the voids of soil layers was pumped using the principle of altering discharge and intermittent pumping after several sets of vacuum-dewatering equipment had been placed in deep wells. Before excavation, free water in soil layers $2-5$ was pumped. After excavation, free water in soil layers 4 and 5 was pumped. Each large well could pump $8.5 \mathrm{~m}^{3}$ of water per day, and each small well could pump $6.5 \mathrm{~m}^{3}$ of water per day. The average daily volumes of water pumped in the east and west excavation sites were about 118 and $125.5 \mathrm{~m}^{3}$, respectively. Groundwater levels were monitored and used as a design parameter for controlling and scheduling dewatering time and extent.

As shown in Table 3, the pumping consolidation resulted in an increase of the field vane shear strength of between 21 and $42 \%$ in soft clay layer 4 . The position and thickness of soft clay layer 4 are given in Figs. 3-5. The pumpingconsolidated zone in layer 4 was about $3 \mathrm{~m}$ thick, which is illustrated in Fig. 5. Further details of pumping consolidation are discussed in Sect. 5.

\subsection{Cement-soil mix piles}

The soft soils adjacent to the diaphragm walls and surrounding the south- and north-bound Metro tunnels were furthered strengthened using piles comprising a cement-soil mix. The cement-soil mix strengthened area can be observed in the cross section in Fig. 5. Plan locations of the cement-soil mix piles for the north-bound Metro tunnel and the diaphragm wall for the east excavation site are given in Fig. 7.

Seven rows of single-head cement-soil mix piles were used for strengthening a $8.2 \mathrm{~m}$ wide soil zone behind each diaphragm wall (Fig. 5). The piles had a staggered plan arrangement. Each pile was $0.7 \mathrm{~m}$ in diameter. The row spacing was $1.35 \mathrm{~m}$, and the center to center spacing of piles in a row was $1.5 \mathrm{~m}$. The piles were $18 \mathrm{~m}$ depth below the original ground level. The replacement ratio of the cement-soil mix piles was $0.15-0.18$ and is defined as the ratio of the plan area occupied by cement-soil mix piles to the total plan area of the soil mass zone to be improved.

The soft soils surrounding the twin Metro tunnels were strengthened using double-head cement-soil mix piles (Figs. 5, 7). Such double-head piles were used to reduce heave and rebound deformation of soft soils surrounding the twin running tunnels. The double-head piles had a rectangular plan arrangement. The spacing between two adjacent longitudinal rows was 1.8 or $2.8 \mathrm{~m}$, and the spacing between two perpendicular rows was $1.3 \mathrm{~m}$. The double-head piles consisted of two single-head piles with an overlapped area of $0.2 \mathrm{~m}$ long along their center to center direction. Each single-head pile was also $0.7 \mathrm{~m}$ in diameter. As shown in Fig. 5, a $2.0 \mathrm{~m}$ soil zone above the twin tunnels was strengthened with the double-head cement-soil mix. This strengthened zone was about $1.0 \mathrm{~m}$ above the crowns of the twin tunnels. The replacement ratio was 0.78 . The design required that the cement-soil mix should have a total shear strength of $\phi=30^{\circ}$ and $c=250 \mathrm{kPa}$. As a result, the heave and deformation of the soils above the twin tunnels could be substantially decreased (Zhu and Shen 1990).

\subsection{Rational excavation procedure}

The construction procedure for the excavation with struts was planned to include the following steps: (1) excavating to a certain depth; (2) installing the first strut; (3) continuing to excavate to the scheduled depth; (4) installing the second strut; and so on. These steps were used until the design depth of the excavation was reached. Such a procedure could, however, lead to an earlier occurrence of lateral displacement in the diaphragm wall. The horizontal displacement of diaphragm walls, which may be called predisplacement, was mainly generated before the struts were installed during the excavation. Each excavation depth is given later in this section.

The magnitude of such pre-displacement depends mainly on the shear strength of the soils in the passive zone of the excavation. The strength and stiffness of the bracing structural system could only prevent further displacement of the diaphragm wall. Consequently, the cement-soil mix piles were used to strengthen the soils in the excavation closely adjacent to the Metro tunnels. As a result, such predisplacement of the diaphragm walls and any plastic slip of the soils behind the wall beneath the Metro tunnels could be effectively reduced.

In view of the apparent rheologic characteristic of the soft soils, a rational excavation procedure was further adopted as illustrated in Figs. 8 and 9. The procedure takes into account the rational planning and sequence of the excavation, including the lifts, plots, symmetry, time, and bracing. Referring to Fig. 9, the steps in the procedure are as follows: (1) excavating the soil in long strip area $\mathrm{I}_{1}$; (2) pouring the reinforced concrete bracing corresponding to the unloading space; (3) excavating the soil in area $\mathrm{II}_{1}$ and installing the corresponding bracing promptly; (4) excavating the soil in area $\mathrm{III}_{1}$; and (5) continuing steps 1-4 for the second, third, and fourth lifts until the design depth of the excavation is achieved.

The first, second, third, and fourth lifts were 2.0, 3.5, 3.0, and $3.0 \mathrm{~m}$ thick, respectively, as shown in Fig. 9. The long strips I, II, and III had lengths of between 21 and $36 \mathrm{~m}$, as shown in Fig. 8. One of the benefits of this construction procedure is to provide stress relief below each excavation lift. Thus, the rebounding heave deformation of soils in the excavation zone could be decreased. Moreover, the bracing construction corresponding to the unloading space could play its part in a timely manner. The potential for the development of lateral displacement in the diaphragm wall could be limited. 
Fig. 7. Plan of cement-soil mixed piles for strengthening the foundation pit. All dimensions in millimetres.

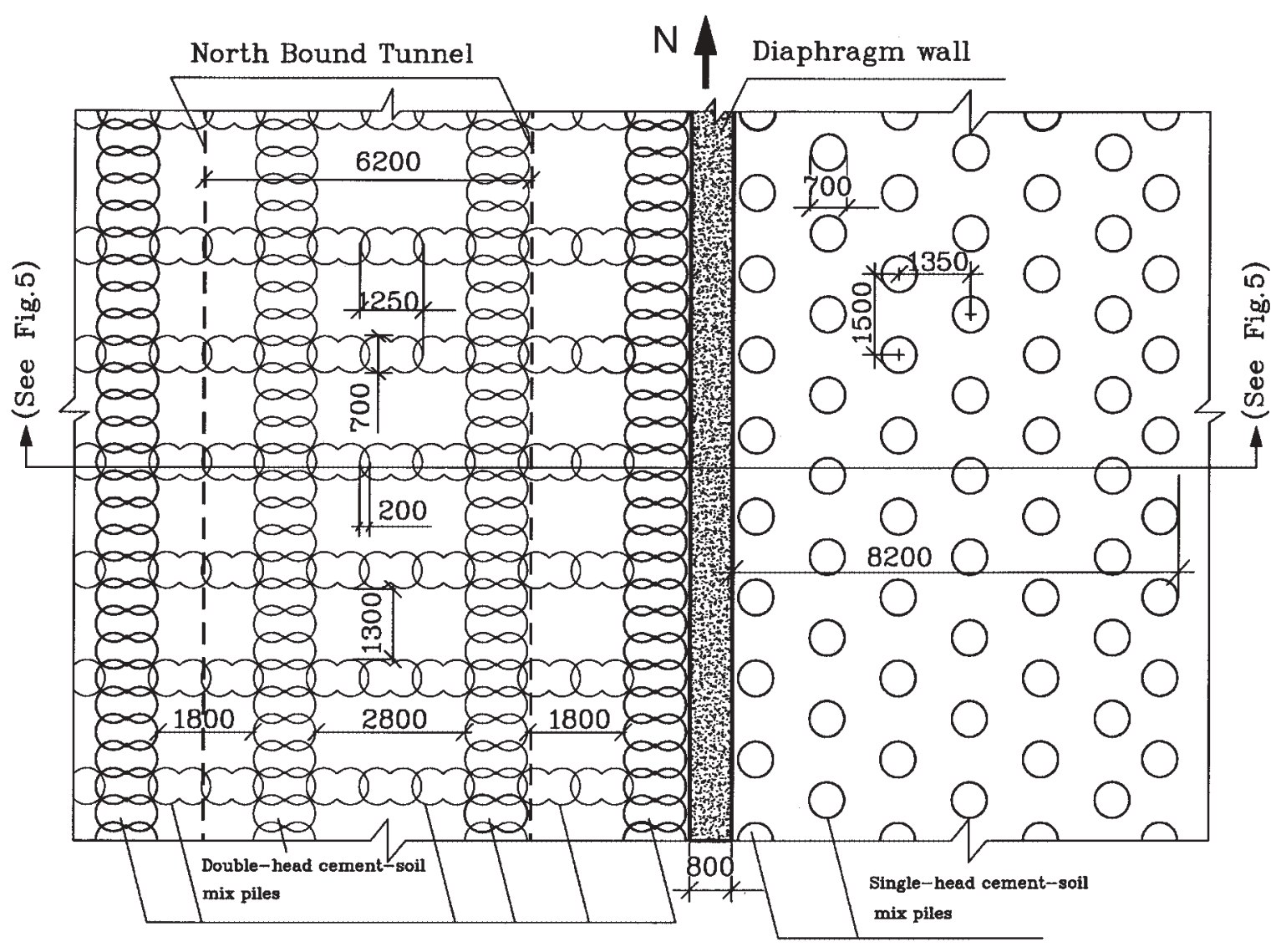

Fig. 8. Plan of the construction sequence for the east portion of the deep excavation at Shanghai New World Commercial City Complex. All dimensions in metres.

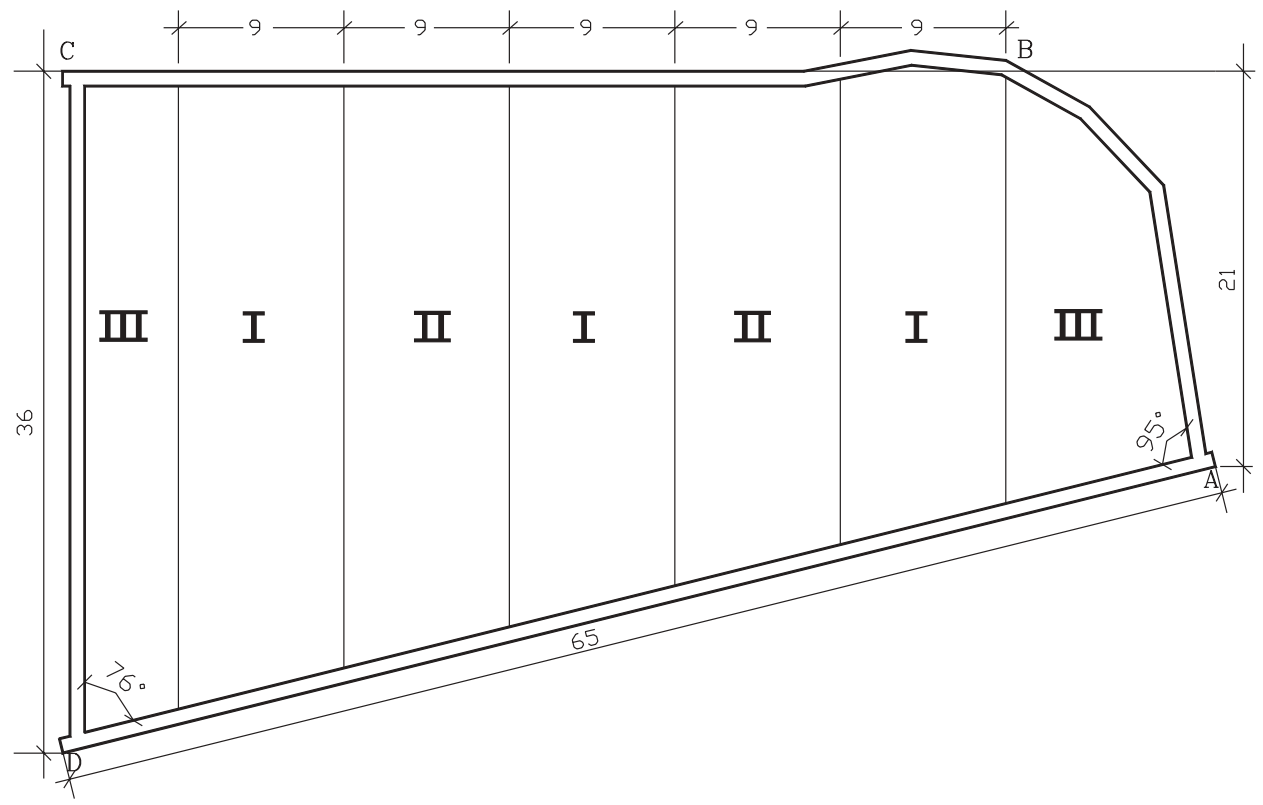


Fig. 9. Profile of the construction sequence for the east portion of the deep excavation at Shanghai New World Commercial City Complex. All dimensions in metres.

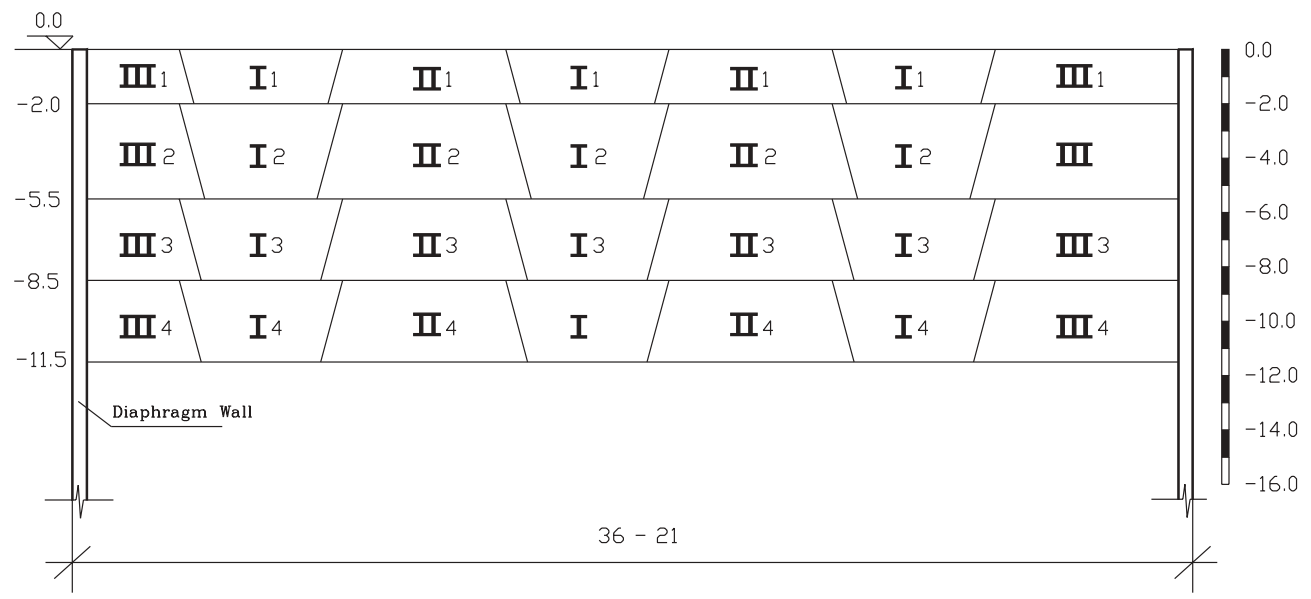

\section{Shear strength increase due to pumping}

\subsection{General}

The pumping-consolidation technique was adopted to improve the soft soil layers below the excavation depth. An attempt was made to estimate the soil shear strength increase due to the pumping consolidation, and the results were used in the design of the pumping and dewatering system discussed in Sect. 4.4.

The east and west excavation pits had their base surface on soft clay layer 4 . This soft clay layer contained various 1-4 mm thick seams of silty and (or) fine sand. Such seams were horizontally positioned and much more permeable than the surrounding clay soils, so they caused a strong crossanisotropy in permeability for layer 4 . It was estimated that the coefficient of horizontal permeability $K_{\mathrm{h}}$ of the soil layers was about 10 times greater than the coefficient of vertical permeability $K_{\mathrm{v}}$ (see Table 2 ). For such a cross-anisotropic clay layer, we proposed the following theoretical method for estimating the increase in its undrained shear strength due to pumping consolidation. Details of the analytical derivation are given in Appendix A.

\subsection{Theoretical method}

According to the directional permeability theory (Bear 1972), the directional permeability coefficient $K_{i}$ of groundwater flowing along the direction of the seepage velocity vector $\overrightarrow{\mathbf{V}}$ can be given by

$$
K_{i}=\frac{2\left(K_{\mathrm{h}} J_{\mathrm{h}}\right)^{2}+\left(K_{\mathrm{v}} J_{\mathrm{v}}\right)^{2}}{2 K_{\mathrm{h}} J_{\mathrm{h}}^{2}+K_{\mathrm{v}} J_{\mathrm{v}}^{2}}
$$

where $J_{\mathrm{h}}$ and $J_{\mathrm{v}}$ are the horizontal and vertical components, respectively, of the water head gradient vector $\overrightarrow{\mathbf{J}}$.

Figure 10 shows the relationship between the water head gradient vector $\overrightarrow{\mathbf{J}}$ and the seepage velocity vector $\overrightarrow{\mathbf{V}}$. The permeability path length $L_{i}$ of groundwater along the direction of the seepage velocity vector $V_{i}$ can be written as

$$
L_{i}=\frac{R_{\mathrm{w}}}{2} \frac{\sqrt{2 K_{\mathrm{h}}^{2}+\left(J_{\mathrm{v}} / J_{\mathrm{h}}\right)^{2} K_{\mathrm{v}}^{2}}}{2 K_{\mathrm{h}}+\left(J_{\mathrm{v}} / J_{\mathrm{h}}\right)^{2} K_{\mathrm{v}}}
$$

where $R_{\mathrm{w}}$ is the shortest drainage distance between two dewatering wells.
Fig. 10. Sketch showing the relation between the seepage velocity $\overrightarrow{\mathbf{V}}=\left(V_{x}+V_{y}+V_{z}\right)$ in an anisotropic soil and the water head gradient vector $\overrightarrow{\mathbf{J}}$.

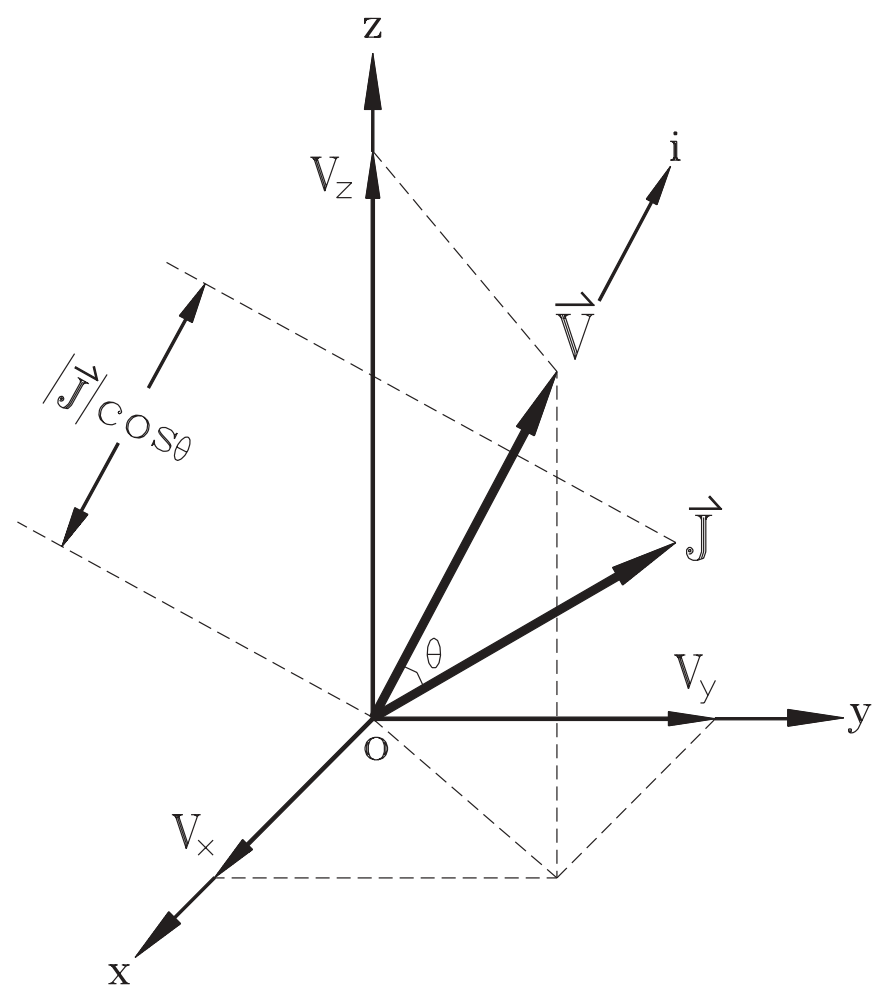

Equations [1] and [2] are further used to apply the Terzaghi one-dimensional theory of soil consolidation to the present pumping-consolidation problem. As a result, the degree of primary consolidation in the saturated soft clay layers below the excavation can be estimated using the following equation:

$$
\begin{aligned}
\bar{U}_{t}=1-\frac{8}{\pi^{2}} \exp \left(-\frac{\pi^{2} K_{i} E_{\mathrm{s}}}{4 L_{i}^{2} \gamma_{\mathrm{w}}} t\right) & \\
& -\frac{8}{9 \pi^{2}} \exp \left(-\frac{9 \pi^{2} K_{i} E_{\mathrm{s}}}{4 L_{i}^{2} \gamma_{\mathrm{w}}} t\right)
\end{aligned}
$$


where $\bar{U}_{t}$ is the average degree of primary consolidation after dewatering and precompression for the soft soils beneath the bottom of the foundation pit, $\gamma_{w}$ is the unit weight of underground water, $E_{\mathrm{s}}$ is the modulus of deformation of soft soil beneath the bottom of the foundation pit, and $t$ is the consolidation time (from the time when the groundwater table was dropped to the bottom level of the excavation to the time when the excavation was commenced).

Based on the effective stress principle and the MohrCoulomb failure criterion, the shear strength increment of the soft soils during the process of the pumping consolidation can be expressed as follows:

$$
\Delta S_{\mathrm{u}}=\left[\gamma_{\mathrm{w}} \Delta H_{\mathrm{w}}\left(1-K_{0}\right) \sqrt{\frac{K_{0}}{2-K_{0}}}\right] \bar{U}_{t}
$$

where $\Delta S_{\mathrm{u}}$ is the increment of drained shear strength of the soft soils beneath the bottom of the excavation because of the pumping consolidation; $\Delta H_{\mathrm{w}}$ is the decrease in height of the groundwater table due to pumping dewatering and can be expressed as $\Delta H_{\mathrm{w}}=H-H_{\mathrm{w}}$, where $H_{\mathrm{w}}$ is the height of the lowest groundwater table at the site in the year before pumping and $H$ is the depth of excavation; and $K_{0}$ is the static earth pressure coefficient of the soft soils beneath the bottom of the excavation.

Using eqs. [1]-[4] it was estimated that the average degree of consolidation of soft soil layer 4 beneath the bottom of the excavation could reach $29 \%$. The average shear strength increment $\Delta S_{\mathrm{u}}$ could be $8.7 \mathrm{kPa}$, which was about $39 \%$ greater than the original undrained shear strength of the soft clay soil.

\subsection{Field test results}

Based on the Shanghai Foundation Standard (Shanghai Construction Commission 1989), in situ electric vane shear tests were carried out at the excavation site 30 days after pumping had started. The tests were conducted in three boreholes at the depths of 1.0, 2.0, and $3.0 \mathrm{~m}$ beneath the bottom of the excavation. The test results are summarized in Table 3 .

Table 3 shows that the average undrained shear strength of soft soil layer 4 beneath the bottom of the excavation increased by $8.0 \mathrm{kPa}$. Such measured results compare well with the values predicted using eqs. [1]-[4].

\section{Finite element method analysis}

\subsection{Computational methods}

It was very important to effectively and accurately predict the displacements induced in the soils and structures by the deep excavation before excavations for full operation of the twin Metro tunnels. Accordingly, a finite element method (FEM) of two-dimensional elastic plane strain theory combined with the model of elastic subgrade beam and member system was adopted for analysis of the deformation. Diaphragm wall displacements were obtained from an elastic subgrade beam and member modeling. Such displacements were taken as known values in the two-dimensional elastic plane strain FEM computation. The computational steps are described as follows: $(i)$ compute horizontal displacements of the diaphragm walls using FEM software with an elastic subgrade beam and member system; (ii) compute soil mass rebound that could be caused by excavation unloading and horizontal displacements of the diaphragm walls using FEM software with two-dimensional elastic plane strain theory; and (iii) using the displacements computed from (i) and (ii) as the initial boundary conditions, compute the deformation of the Metro tunnels induced by excavation unloading.

The characteristics of different soft soil layers and the treatment of many different material zones were rationally taken into account in subdividing the FEM meshes. These characteristics include the bearing piles of surrounding buildings, tunnel lining structures, diaphragm walls, soil strengthening due to pumping precompression, and cementsoil mix piles.

\subsection{Parameters for computation}

Table 4 gives the mechanical parameters for the in situ soils, improved soils, cement-soil mix piles, diaphragm walls, building bearing piles, and tunnel concrete structures. In the FEM modeling of elastic subgrade beam and member system, lateral earth pressure distributions were taken as triangular and rectangular. The distributions are triangular with a 1.3 slope gradient on the excavation plane and rectangular under the excavation plane. The distributions of horizontal spring stiffness coefficient of the elastic subgrade in the excavation were also considered as two distributions. They have a triangular distribution with a 1.3 slope gradient within $1 \mathrm{~m}$ depth under the excavation plane and a rectangular distribution outside $1 \mathrm{~m}$ depth under the excavation plane. In addition, the maximum horizontal spring stiffness coefficient is $1.875 \times 10^{4} \mathrm{kN} / \mathrm{m}^{3}$.

\subsection{FEM and measured results}

Figures 11-14 show the horizontal and vertical displacement contour lines predicted using the FEM in the soft soil layers around the excavation. In these figures, the abscissa represents horizontal distance, and the vertical ordinate represents depth, with the assumption that ground elevation is at $0.0 \mathrm{~m}$. The contour lines indicating displacement are in millimetres. Because of soil improvement using cement-soil mix piles and pumping consolidation, the predicted displacements in the soils due to excavation were less than $15 \mathrm{~mm}$. More specifically, the excavation at the east pit could cause horizontal soil displacement of less than $11 \mathrm{~mm}$ toward the diaphragm wall and maximum soil settlement of less than $7 \mathrm{~mm}$ on the ground above the north-bound tunnel. The excavation at both the east and west pits could cause horizontal soil displacement of less than $13 \mathrm{~mm}$ toward the two diaphragm walls and maximum soil settlement of less than $4 \mathrm{~mm}$ on the ground surface above the twin tunnels.

Furthermore, a comparison between the calculated and measured results for the horizontal displacement of the diaphragm wall with depth is shown in Fig. 15. It is evident from Fig. 15 that the calculated results compare well with the measured results. The maximum horizontal displacement of the diaphragm wall was $14.2 \mathrm{~mm}$, which occurred about $2 \mathrm{~m}$ above the base of the excavation. Such horizontal displacement of the bracing structures is less than $0.12 \%$ of the total excavation depth, which satisfied the design criteria.

The predicted result was obtained using the FEM modeling of the elastic subgrade beam and member system. De- 
Table 4. Design parameters for finite element modeling of the tunnel deformation due to deep excavation.

\begin{tabular}{|c|c|c|c|c|c|}
\hline Materials & $\begin{array}{l}\text { Unit weight, } \\
\gamma\left(\mathrm{kN} / \mathrm{m}^{3}\right)\end{array}$ & $\begin{array}{l}\text { Cohesion, } \\
c(\mathrm{kPa})\end{array}$ & $\begin{array}{l}\text { Angle of internal } \\
\text { friction, } \phi\left(^{\circ}\right)\end{array}$ & $\begin{array}{l}\text { Modulus of } \\
\text { deformation } \\
(\mathrm{MPa})\end{array}$ & $\begin{array}{l}\text { Poisson's } \\
\text { ratio }\end{array}$ \\
\hline Reinforced concrete for tunnels & 25.0 & - & - & 21700 & 0.20 \\
\hline Diaphragm walls & 25.0 & - & - & 21700 & 0.20 \\
\hline Cement-soil mixed piles & 18.5 & - & - & 500 & 0.28 \\
\hline Bearing piles of building & 24.0 & - & - & 15000 & 0.20 \\
\hline Strengthened soil body & 17.8 & 250 & 30 & 100 & 0.30 \\
\hline Layer 2 silty clay & & & & 5.0 & 0.42 \\
\hline Layer 3 very soft silty clay & & & & 5.0 & 0.40 \\
\hline Layer 4 very soft silty clay & & & & 3.0 & 0.40 \\
\hline Layer 5-1 clay & & & & 5.0 & 0.40 \\
\hline Layer 5-2 silty clay & & & & 4.0 & 0.40 \\
\hline Layer 6 silty clay & & & & 8.0 & 0.40 \\
\hline Layer 7 silty sand & & & & 27.5 & 0.40 \\
\hline
\end{tabular}

Note: For unit weight, cohesion, and angle of internal friction values for layers 2-7. see Table 2.

Fig. 11. Predicted contours of the horizontal displacement $(\mathrm{mm})$ distribution for the soil and tunnels due to the deep excavation at the east portion.

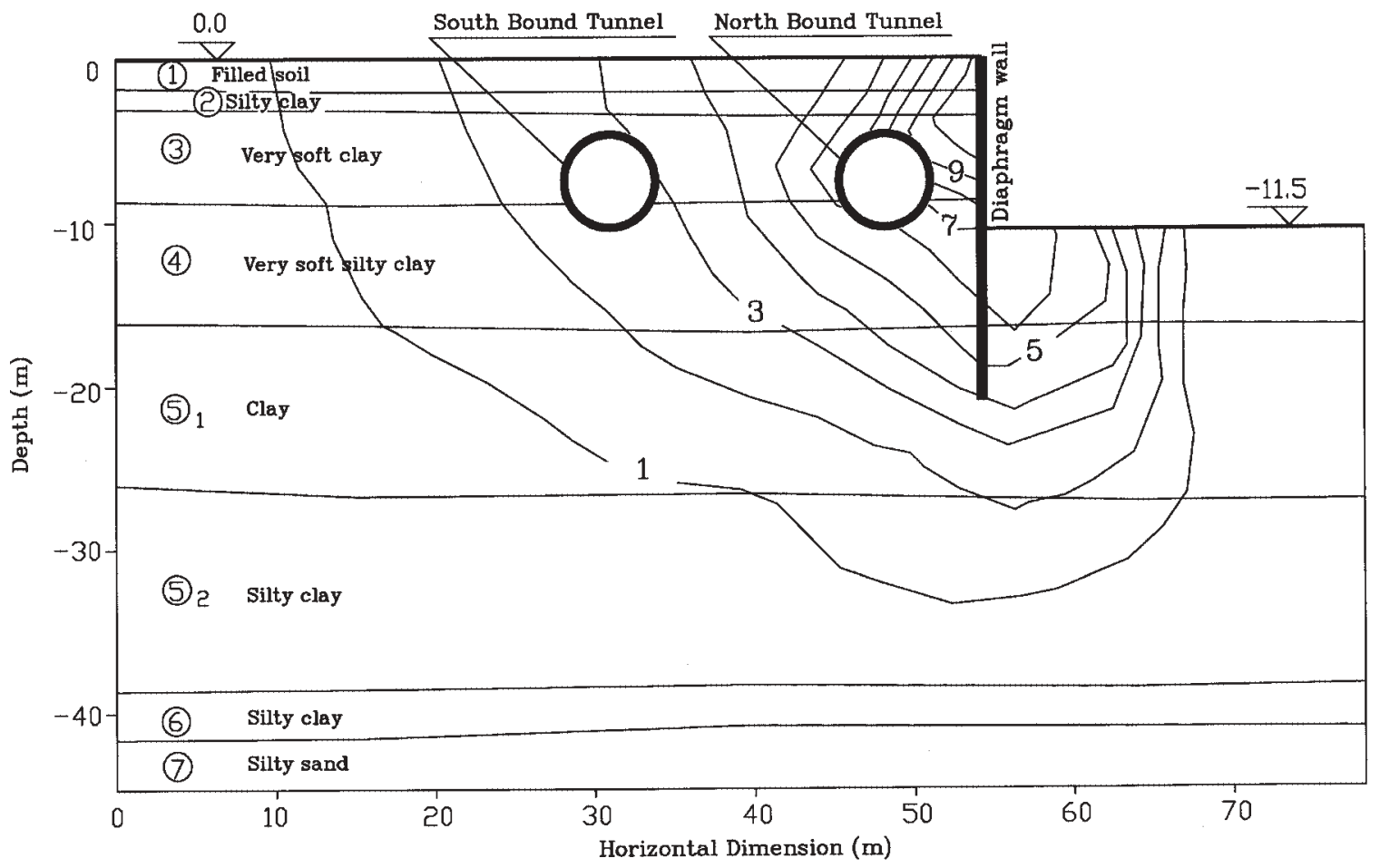

tails of this method can be found in Gong (1998). Such predicted diaphragm wall deformation is also similar to the results of horizontal soil displacements behind the diaphragm walls as shown in Figs. 11 and 13. Furthermore, the field measurement of diaphragm wall deflection in Fig. 15 was carried out in an inclinometer pipe in the diaphragm wall. Plan location of the inclinometer is shown in Fig. 2. The inclinometer pipe was installed together with the diaphragm wall reinforcements. Cast-in-place concrete was later applied to form the diaphragm wall together with the inclinometer pipe. The inclinometer pipe was $21 \mathrm{~m}$ long and equal to the wall height.

\section{Deformation performance of Metro tunnels}

Figures 16 and 17 show the measured curves for horizontal and vertical displacements along the north- and southbound Metro tunnel alignments, respectively. Plan locations of the measurement points $\mathrm{C} 1-\mathrm{C} 11$ in Fig. 16 and S1-S8 in Fig. 17 are shown in Fig. 2. The exact measurement position was the crown on the internal surface of each of the twin operating tunnels.

The measured results indicate that the design and construction measures present in this paper were effective and 
Fig. 12. Predicted contours of the vertical displacement $(\mathrm{mm})$ distribution for the soil and tunnels due to the deep excavation at the east portion.

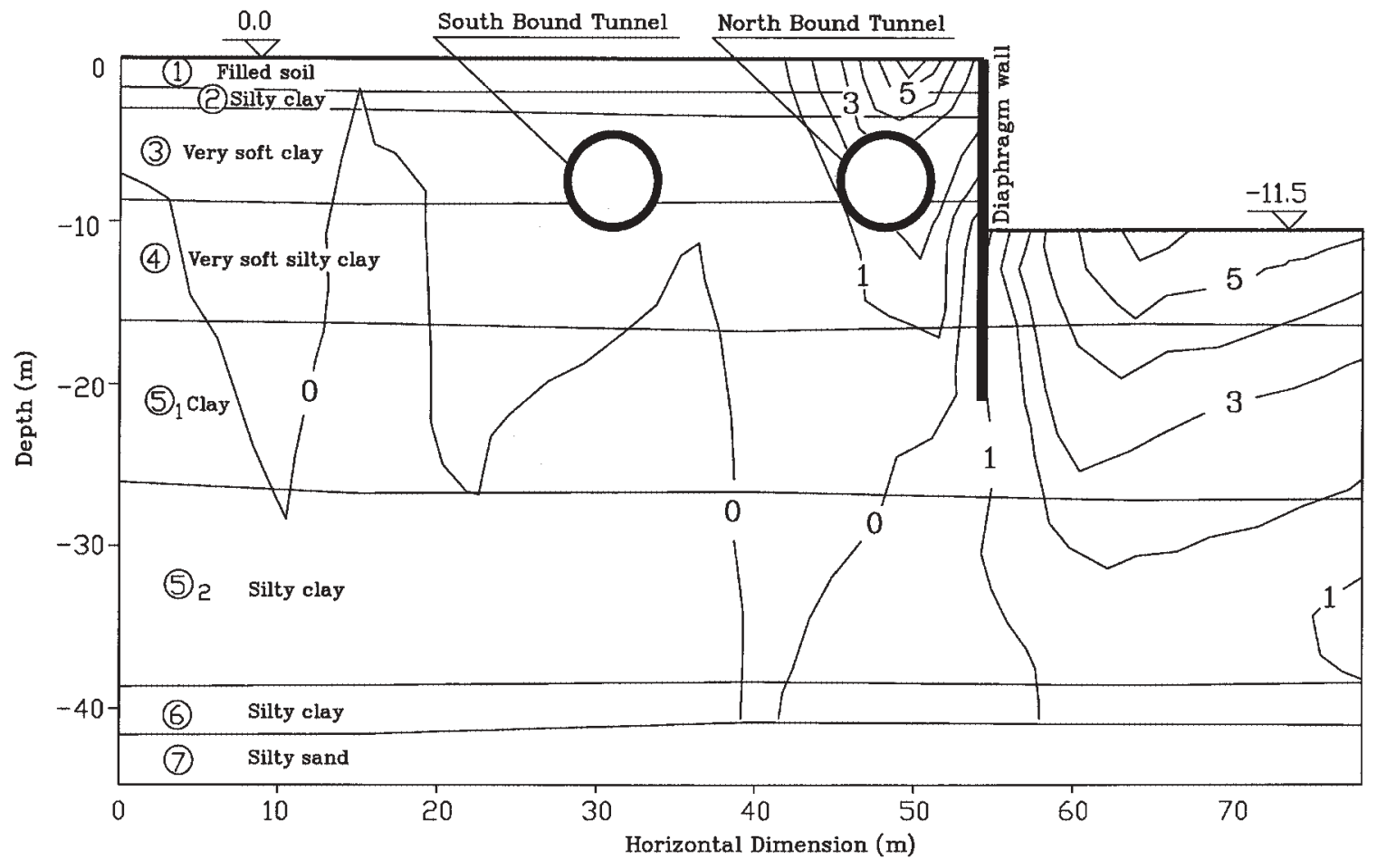

Fig. 13. Predicted contours of the horizontal displacement $(\mathrm{mm})$ distribution for the soil and tunnels due to the deep excavation at the east and west portions.

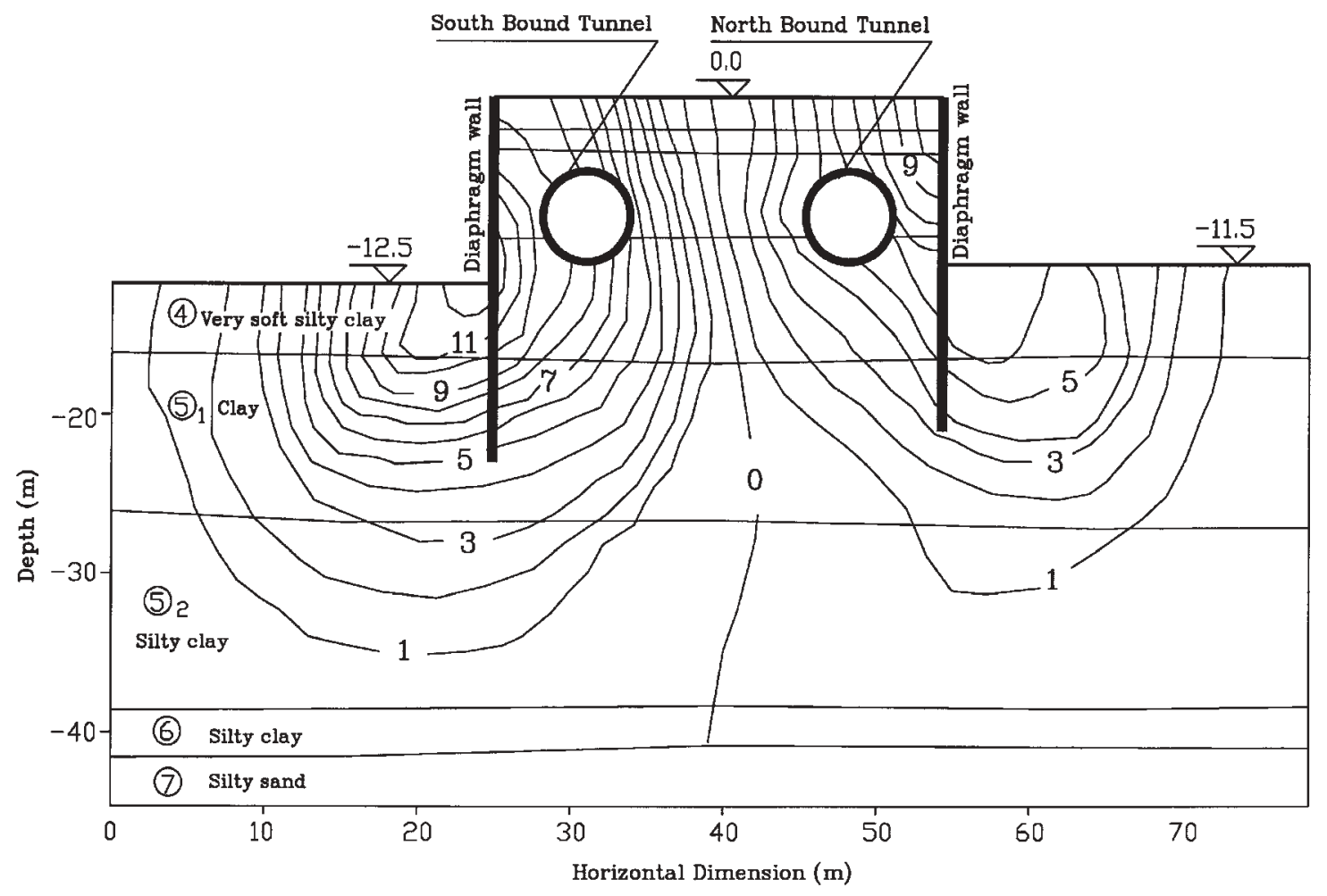


Fig. 14. Predicted contours of the vertical displacement $(\mathrm{mm})$ distribution for the soil and tunnels due to the deep excavation at the east and west portions.

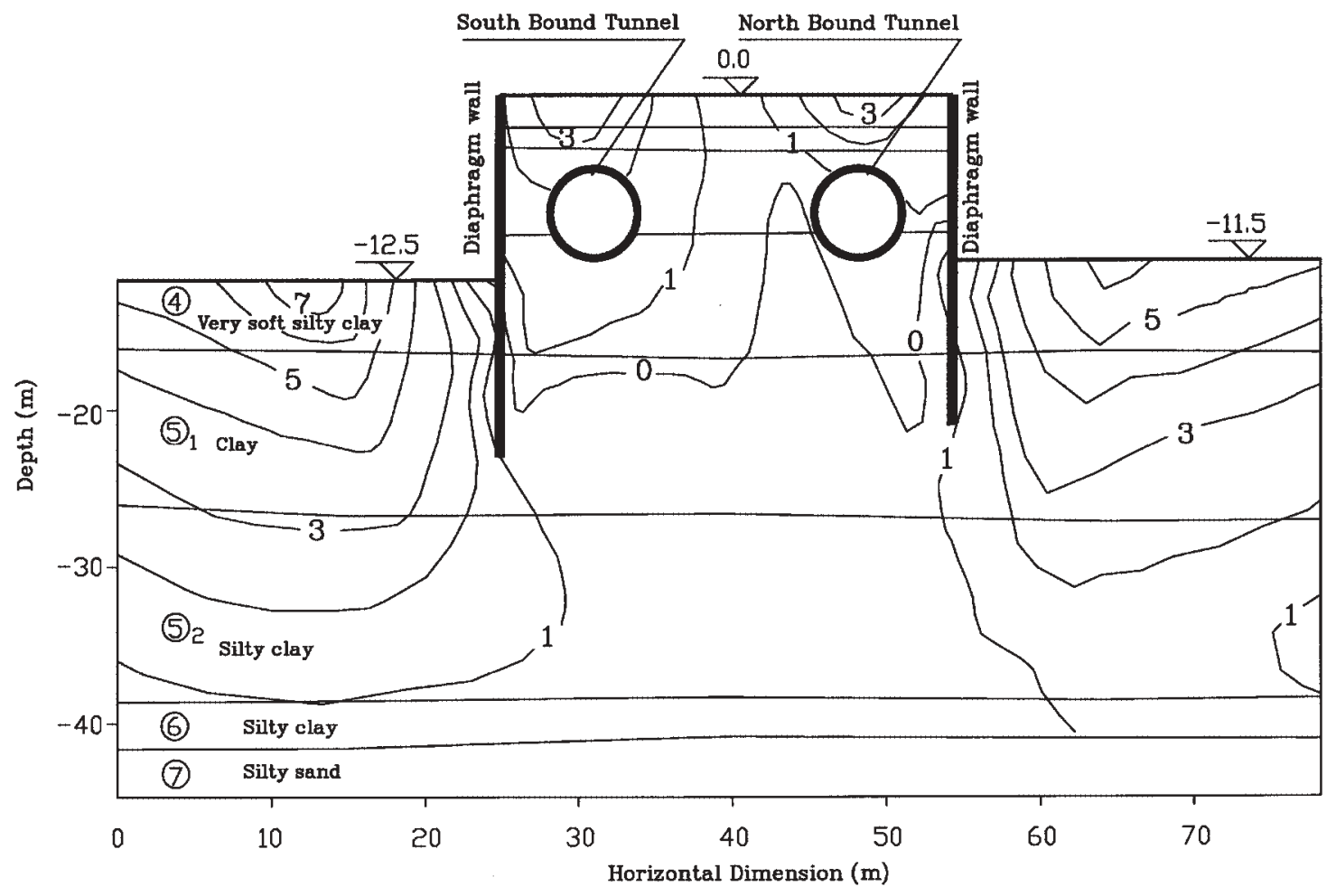

successful in controlling deformation of the Metro tunnels associated with the deep excavation. The settlement and horizontal displacement of the tunnels were successfully controlled within 5.0 and $9.0 \mathrm{~mm}$, respectively. The curvature of the longitudinal deformation curve of the tunnels was less than 1/15000, which satisfies the design criteria. Furthermore, from the predicted results in Figs. 11-14, it is evident that the soil surrounding the twin tunnels had levels of maximum horizontal and vertical displacements similar to those shown in Figs. 16 and 17.

\section{Conclusions}

In this paper we have presented the design and construction of the deep excavation of a commercial building closely above and beside the Shanghai Metro tunnels. From the studies, we make the following conclusions:

(1) For deep excavations in saturated soft soils and closely adjacent to the twin Metro tunnels, it is very important to adopt deformation control based design and construction measures.

(2) For the deep excavation discussed in this paper, the combined design and construction measures have successfully resulted in maintaining the measured deformations within the criteria that were required to control deformation of the operating Metro tunnels. These measures include the diaphragm walls with bracing members, pumping consolidation for saturated soft clay soils below the excavation, cement-soil mix piles behind the diaphragm walls and around the twin tunnels, and rational excavation procedures for reduction of immediate soil deformation.
(3) The combined efforts of pumping consolidation, cementsoil mix piles, and rational excavation procedures led to a reduction of the diaphragm wall horizontal maximum displacement from a predicted $28.5 \mathrm{~mm}$ to about $14.2 \mathrm{~mm}$ and a reduction of the ground soil vertical maximum settlement from a predicted $23.1 \mathrm{~mm}$ to about $7 \mathrm{~mm}$. Such reductions in displacement were effective and useful for protecting the normal operation of the twin Metro tunnels. The settlement and horizontal displacement of the tunnels were controlled within 5.0 and $9.0 \mathrm{~mm}$, respectively. The curvatures of the longitudinal deformation curves of the twin tunnels were less than $1 / 15000$. The horizontal displacement of the braced diaphragm walls was less than $0.12 \%$ of the total excavation depth.

(4) A simplified theoretical method was proposed for estimating the increase in undrained shear strength in saturated soft clay with cross-anisotropic permeability due to pumping consolidation. This method was used in the design of the dewatering wells and pumping system. The predicted increase in undrained shear strength is close to that measured in the field.

(5) Finite element methods were used for elastic analysis of the deformation of the soil and concrete system surrounding the operating tunnels due to deep excavations in the east and west foundation pits. The soil and concrete system included in situ soils, pumping consolidated clay, cement-soil mix piles, diaphragm wall, and tunnel lining concrete structure. The results from this elastic analysis were very close to the displacements or settlements measured in the diaphragm wall or at the tunnel internal crowns. Such theoretical predictions enhanced the design and construction measures of the 
Fig. 15. Comparison of the predicted and measured horizontal displacements of the diaphragm wall with depth.

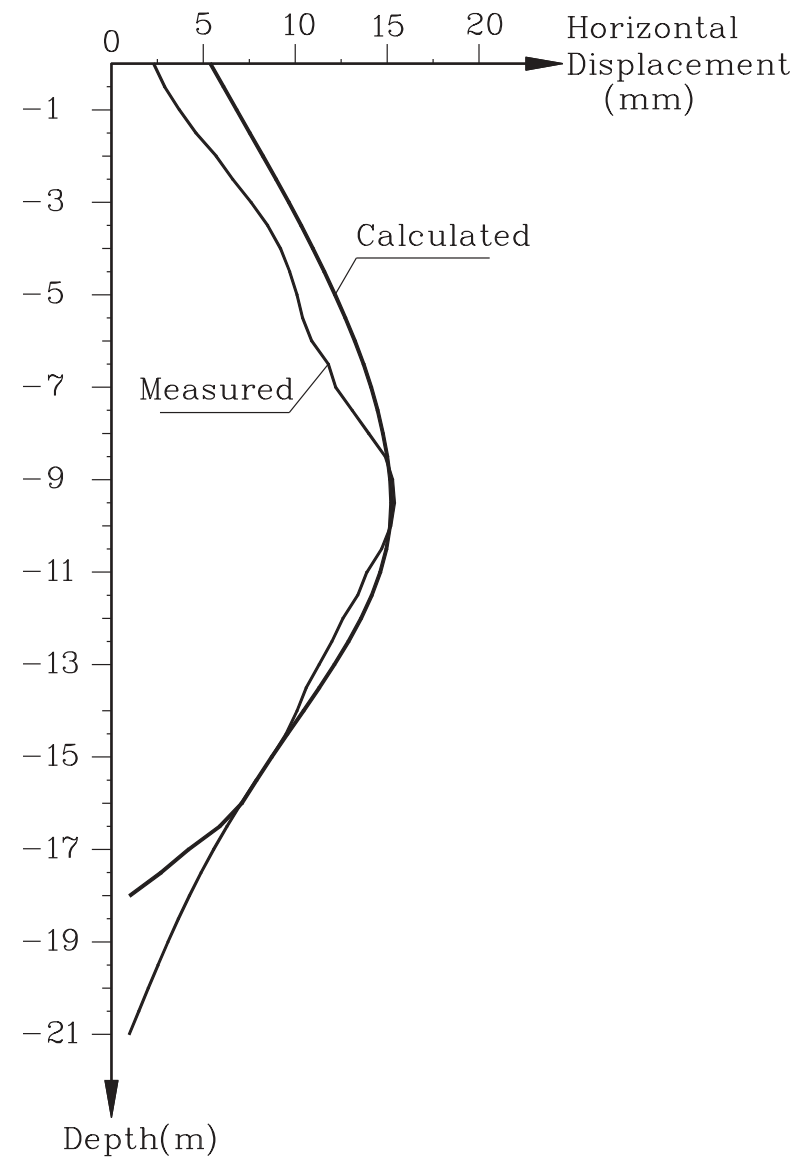

deep excavation in soft soils surrounding the Metro tunnels, which were in full operation during the excavation. It was also critical to select correct values for the mechanical parameters in the theoretical predictions. Good knowledge and experience of the local soft soil conditions and properties were assets in the selection of the parameter values for prediction.

(6) The soft clay layer 4 shows high cross-anisotropy in soil permeability. Such cross-anisotropy was examined and taken into account in the analysis of the undrained shear strength increment due to dumping consolidation. It would be useful and interesting to further examine the cross-anisotropy in the soil shear strength and modulus and its effect on the soil deformation due to deep excavation, although such an effect might not be important.

(7) Lastly, it is noted that the deep excavation and other building construction activities have been completed for more than 3 years and both the commercial buildings and the Metro tunnels continue to function well.

\section{Acknowledgements}

The authors would like to thank the Research Grants Council of the Hong Kong SAR Government for financial support and the Editor, Professor A.J. Valsangkar, Associate Editor, and two peer reviewers for their valuable comments and suggestions, which have enhanced the paper presentation.
Fig. 16. Variation of the measured horizontal displacement of the north bound tunnel along its longitudinal direction.

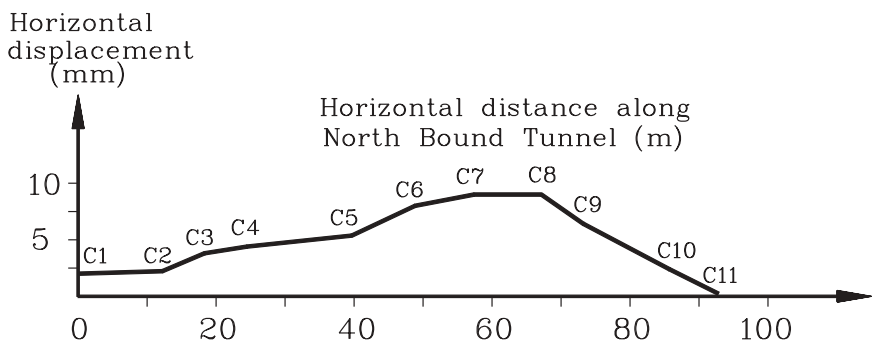

Fig. 17. Variation of the measured vertical displacement of the south bound tunnel along its longitudinal direction.

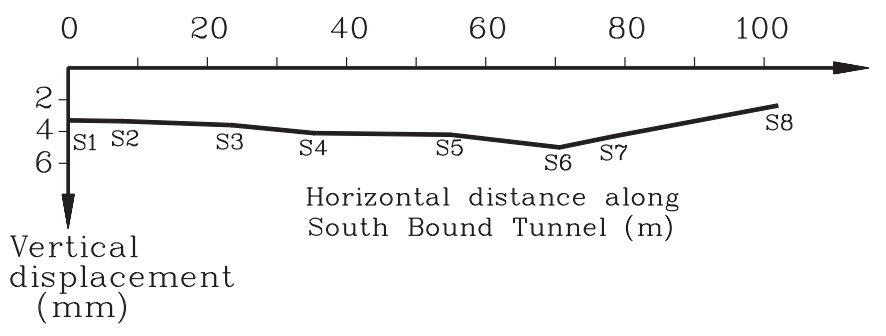

\section{References}

Bear, J. 1972. Dynamics of fluids in porous media. American Elsevier Publishing Co., New York.

Gong, X.N. 1998. Handbook for design and construction of deep excavation pits. China Construction Industries Publisher, Beijing, China.

Liu, J.H. 1999. Environmental protection technology of Shanghai Metro and its adjacent buildings Construction. Shanghai Building Science and Technology, No. 2, Shanghai, China. [In Chinese].

Shanghai Construction Commission. 1989. Shanghai standard foundation design code (DBJ08-11-89). Shanghai Construction Commission (SCC), Shanghai, China. [In Chinese].

Sun, G.S., and Zheng, D.T. 1987. Soft foundations and underground engineering. China Architecture \& Building Press, Beijing, China. [In Chinese].

Zhu, B.L., and Shen, Z.J. 1990. Computational soil mechanics. Shanghai Science and Technology Press, Shanghai, China. [In Chinese].

\section{Appendix A: Shear strength increase in a saturated cross-anisotropic clay layer due to pumping consolidation}

According to the directional permeability theory (Bear 1972) and using the Cartesian coordinate system in Fig. 10, the directional permeability coefficient $K_{i}$ of groundwater flowing along the direction of the seepage velocity vector $\overrightarrow{\mathbf{V}}$ can be given by

$$
K_{i}=\frac{K_{x}^{2} J_{x}^{2}+K_{y}^{2} J_{y}^{2}+K_{\mathrm{v}}^{2} J_{\mathrm{v}}^{2}}{K_{x} J_{x}^{2}+K_{y} J_{y}^{2}+K_{\mathrm{v}} J_{\mathrm{v}}^{2}}
$$

For soil with cross-anisotropy and seepage flow, we have $K_{x}=K_{y}=K_{\mathrm{h}}$ and $J_{x}=J_{y}=J_{\mathrm{h}}$, where $J_{\mathrm{h}}$ and $J_{\mathrm{v}}$ are the horizontal and vertical components, respectively, of the water 
head gradient vector $\overrightarrow{\mathbf{J}}$. Equation [A1] can be reduced as follows:

$$
K_{i}=\frac{2\left(K_{\mathrm{h}} J_{\mathrm{h}}\right)^{2}+\left(K_{\mathrm{v}} J_{\mathrm{v}}\right)^{2}}{2 K_{\mathrm{h}} J_{\mathrm{h}}^{2}+K_{\mathrm{v}} J_{\mathrm{v}}^{2}}
$$

Using Darcy's Law, we have the following equation for the seepage velocity along the $i$ direction:

[A3] $V_{i}=K_{i} J_{i}=\frac{K_{i} \Delta H}{L_{i}}$

where $\Delta H$ is the groundwater table head difference, and $L_{i}$ is a drainage path along the $i$ direction.

Using eqs. [A2] and [A3] we have

$$
V_{i}=\frac{2 K_{\mathrm{h}}^{2}+K_{\mathrm{v}}^{2}\left(J_{\mathrm{v}} / J_{\mathrm{h}}\right)^{2}}{2 K_{\mathrm{h}}+K_{\mathrm{v}}\left(J_{\mathrm{v}} / J_{\mathrm{h}}\right)^{2}} \frac{\Delta H}{V_{i}}
$$

As a result, we have the following equation for the drainage path length:

$$
L_{i}=\frac{2 K_{\mathrm{h}}^{2}+K_{\mathrm{v}}^{2}\left(J_{\mathrm{v}} / J_{\mathrm{h}}\right)^{2}}{2 K_{\mathrm{h}}+K_{\mathrm{v}}\left(J_{\mathrm{v}} / J_{\mathrm{h}}\right)^{2}} \frac{\Delta H}{L_{i}}
$$

We further assume $V_{i}=\sqrt{V_{x}^{2}+V_{y}^{2}+V_{\mathrm{v}}^{2}}$ and the axisymmetrical flow $V_{x}=V_{y}=V_{\mathrm{h}}$. We then have

[A6] $V_{i}=\sqrt{2 V_{\mathrm{h}}^{2}+V_{\mathrm{v}}^{2}}$

Since $V_{\mathrm{h}}=K_{\mathrm{h}} J_{\mathrm{h}}$ and $V_{\mathrm{v}}=K_{\mathrm{v}} J_{\mathrm{v}}$, we have

[A7] $V_{i}=J_{\mathrm{h}} \sqrt{2 K_{\mathrm{h}}^{2}+K_{\mathrm{v}}^{2}\left(J_{\mathrm{v}} / J_{\mathrm{h}}\right)^{2}}$

Equation [A5] can be further written as follows:

$$
L_{i}=\frac{\sqrt{2 K_{\mathrm{h}}^{2}+K_{\mathrm{v}}^{2}\left(J_{\mathrm{v}} / J_{\mathrm{h}}\right)^{2}}}{2 K_{\mathrm{h}}+K_{\mathrm{v}}\left(J_{\mathrm{v}} / J_{\mathrm{h}}\right)^{2}} \frac{\Delta H}{J_{\mathrm{h}}}
$$

Since $J_{\mathrm{h}}=\Delta H / L_{\mathrm{h}}$, we can further simplify eq. [A8] as follows:

[A9] $\quad L_{i}=\frac{\sqrt{2 K_{\mathrm{h}}^{2}+K_{\mathrm{v}}^{2}\left(J_{\mathrm{v}} / J_{\mathrm{h}}\right)^{2}}}{2 K_{\mathrm{h}}+K_{\mathrm{v}}\left(J_{\mathrm{v}} / J_{\mathrm{h}}\right)^{2}} \frac{1}{L_{\mathrm{h}}}$

where $L_{\mathrm{h}}$ is the radial drainage path length. For simplicity, we select $L=R_{\mathrm{w}} / 2$, where $R_{\mathrm{w}}$ is the distance between the two closest wells.

According to the one-dimensional theory, we have the following equation for the average degree of consolidation $\bar{U}_{t}$ :

$$
\bar{U}_{t}=1-\frac{8}{\pi^{2}}\left[\exp \left(-\frac{\pi^{2}}{4} T\right)+\frac{1}{9} \exp \left(-\frac{9 \pi^{2}}{4} T\right)+\ldots\right]
$$

where $T=\left(K E_{\mathrm{s}} t\right) /\left(\gamma_{\mathrm{w}} H^{2}\right)$, in which $t$ is the consolidation time, $K$ is the permeability, $\gamma_{\mathrm{w}}$ is the unit weight of groundwater, $E_{\mathrm{s}}$ is the soil modulus of compressibility, and $H$ is the drainage path distance.

Furthermore, assuming $H=L_{i}$ and $K=K_{i}$, we can find eq. [A10] as follows:
[A11] $\bar{U}_{t}=1-\frac{8}{\pi^{2}}\left[\exp \left(-\frac{\pi^{2} K_{i} E_{\mathrm{s}}}{4 L_{i}^{2} \gamma_{\mathrm{w}}} t\right)+\frac{1}{9} \exp \left(-\frac{9 \pi^{2} K_{i} E_{\mathrm{s}}}{4 L_{i}^{2} \gamma_{\mathrm{w}}} t\right)\right]$

On the other hand, the undrained shear strength $S_{\mathrm{u}}$ at a point in a consolidating soft soil can be expressed as follows (Sun and Zheng 1987):

[A12] $S_{\mathrm{u}}=\eta\left(S_{0}+\Delta S_{\mathrm{c}}\right)$

where $S_{0}$ is the in situ original undrained shear strength, $\Delta S_{\mathrm{c}}$ is the increment of undrained shear strength due to consolidation, and $\eta$ is the reduction factor due to soil creep under shear. $\Delta S_{\mathrm{c}}$ can be further expressed as follows:

[A13] $\Delta S_{\mathrm{c}}=K_{1} \Delta \sigma_{1} U$

where $\Delta \sigma_{1}$ is the increment in the maximum principal stress due to surcharge and can be approximately equal to the increment in the in situ vertical stress $\Delta \sigma_{\mathrm{v}}, U$ is the degree of consolidation corresponding to $\Delta \sigma_{1}$, and $K_{1}$ is a soil coefficient and can be expressed as follows:

[A14] $K_{1}=\frac{\sin \phi^{\prime} \cos \phi^{\prime}}{1+\sin \phi^{\prime}}$

where $\phi^{\prime}$ is the soil effective internal friction angle.

In this study, we need to estimate the increment in undrained shear strength due to pumping consolidation. We can express the increment in undrained shear strength $\Delta S_{\mathrm{u}}$ as follows:

\section{[A15] $\Delta S_{\mathrm{u}}=\eta K_{1} \Delta \sigma_{1} U$}

During pumping consolidation, the foundation pits were not excavated and were confined by diaphragm walls, so such pumping consolidation would not cause substantial creep deformation in the soft soils. Therefore, we can assume that $\eta=1$. Furthermore, the increment in the maximum principal stress $\Delta \sigma_{1}$ can be expressed as follows:

[A16] $\Delta \sigma_{1}=\gamma_{\mathrm{w}} \Delta H_{\mathrm{w}}$

where $\Delta H_{\mathrm{w}}$ is the decrease in groundwater table due to pumping dewatering.

In addition, the soil coefficient $K_{1}$ has the following relationship with the static earth pressure coefficient $K_{0}(=1-$ $\sin \phi^{\prime}$ ) of the soft soils beneath the bottom of the excavation:

[A17] $K_{1}=\left(1-K_{0}\right) \sqrt{\frac{K_{0}}{2-K_{0}}}$

Therefore, we can have the following equation governing the undrained shear strength increment due to pumping consolidation at the degree of consolidation $U$ :

$$
\Delta S_{\mathrm{u}}=\left[\gamma_{\mathrm{w}} \Delta H_{\mathrm{w}}\left(1-K_{0}\right) \sqrt{\frac{K_{0}}{2-K_{0}}}\right] U
$$

Using the average degree of soil consolidation in eq. [A11], we can express the average increment in the undrained shear strength for a clay layer as follows:

$$
\Delta S_{\mathrm{u}}=\left[\gamma_{\mathrm{w}} \Delta H_{\mathrm{w}}\left(1-K_{0}\right) \sqrt{\frac{K_{0}}{2-K_{0}}}\right] \bar{U}_{t}
$$

